\title{
How Efficient is the Foreign Exchange Market?
}

\author{
By Ioannis N. Kallianiotis*
}

In this paper, we try to measure the degree of efficiency in the foreign exchange market by using four exchange rates (\$/€, $\$ / £, C \$ / \$$, and $¥ / \$)$. Different theoretical models are applied, like the random walk hypothesis, the unbiased forward rate hypothesis, the composite efficiency hypothesis, the semi-strong market efficiency, and the exchange rate expectations based on anticipated and unanticipated events ("News"). If exchange rate efficiency does not hold, a risk premium must exist and can be measured. Also, the determination of this exchange risk premium is taking place by using a GARCH $(p, q)$ model. The empirical results for these four major exchange rates (five currencies) show that relative efficiency exists, but there are significant risk premia for some exchange rates used, here.

Keywords: Demand for Money and Exchange Rate, Foreign Exchange, Forecasting and Simulation, Information and Market Efficiency, International Financial Markets

\section{Introduction}

The latest global financial crisis has proved that the financial markets are not very efficient and their deregulation has caused serious risk and wealth redistribution problems. The international monetary system had to accommodate extraordinarily large oil-related shocks, monetary shocks, trade deficits, privatizations (sell-offs of State Own Enterprises), Foreign Direct Investments, outsourcings, globalization, and public and private debts that affect capital flows among nations, and risk. Surpluses had to be recycled (invested) by buying financial assets from the deficit countries, which are at a low market price (undervalued) and the benefits to the sellers are insignificant. The continuous financial and debt crises have increased uncertainty and the deregulation of our financial institutions has increased the gap ("brain spread") between the market and liberal politicians and deteriorated the agency problem between people (the principals) and government-market (the agents). Labor has lost some its rights and it is exploited in many countries, as Chomsky (2014) says. ${ }^{1}$ The increased interdependence among nations, due to globalization, and the realization that economic policies by strong nations exert pressure on other weaker economies,

${ }^{*}$ Economics/Finance Department, The Arthur J. Kania School of Management, University of Scranton, USA.

${ }^{1}$ From permanent full-time jobs with healthcare coverage, they became half-time ones without healthcare benefits and now, part-time with minimum wages without any benefits. And they (the liberals) have the impudence to call this planned labor crisis, as full employment and give an official unemployment rate for the U.S. of 4.5\% (March 2017), See, http://data.bls.gov/time series/LNS14000000. But, the unofficial unemployment rate is 22.5\% (March 2017). See, http://www.shadowstats.com/alternate_data/unemployment-charts. Further, for $u_{U K}=4.7 \%$, $u_{C}=6.7 \%$, and $u_{J}=2.8 \%$. http://www.tradingeconomics.com/canada/unemployment-rate. 
has to induce legal responses and cooperation among all nations. But, what international organization can force objectively international justice? As Kallianiotis (2017b) shows, there is none.

An understanding of efficiency, expectations, risk, and risk premium in the foreign exchange market is important to government and central bank policymakers, international financial managers, and of course, to investors and to everyone interested in international finance. The government policymakers need to design macro-policies for achieving the goal of maximization of their social welfare through efficient resource allocation. Central banks have to be public and responsible for the wellbeing of the citizens of their own country. International investors and financial managers need to assess foreign asset returns, risks, and their correlations in order to make optimal portfolio decisions. ${ }^{2}$ The foreign exchange market efficiency hypothesis is the proposition that prices (exchange rate movements) fully reflect information available to market participants. There are no opportunities for hedgers or speculators to make super-normal profits; thus, both speculative efficiency and arbitraging efficiency exist. Numerous studies have been tested for speculative efficiency and arbitraging efficiency by testing the following three hypotheses respectively: (1) The forward discount or premium is a good predictor of the change in the future spot rate, implying covered interest parity (CIP), uncovered interest parity (UIP), and rational expectations to hold. (2) The forward discount tends to be equal to the interest differential, implying that CIP holds. (3) The expected risk premium is zero $\left(s_{t+1}^{e}-f_{t}=r p_{t+1}^{e}=0\right)$, as Kallianiotis (2016b) mentions. In case that a risk premium exists $\left(r p_{t} \neq 0\right)$, its determination and the factors that affect it will be important to be defined and assessed.

Further, exchange rates are viewed as relative prices of two assets (actually, two central banks' liabilities, ${ }^{3}$ their currencies) that are traded in organized markets (the foreign exchange market) and are influenced by interest rates and many different domestic factors (fundamentals) and of course, by expectations about the future international events ("news") and the futures markets. Therefore, unanticipated events will influence the exchange rates, too, as it happens with other assets. So far, the flexible exchange rate system has been successful in providing national economies with an added degree of insulation from foreign shocks and it provides policymakers with an added instrument for the conduct of trade policy and improving the terms of trade and the current account, as Kallianiotis (2013a) shows. Unfortunately, the Eurozone member-nations (due to their acceptance and imperative ever since euro, which is controlled by the ECB) have lost this valuable macroeconomic policy tool, their national currencies, as Kallianiotis (2012) says and for this reason, they could not cope with their recessions from 2009 up 2016.

\footnotetext{
${ }^{2}$ The optimal portfolio is the one that minimizes its risk $\left(\sigma_{P}\right)$ and this to happen, the correlation of its securities must be $\left(\rho_{i, j}=-1\right)$. Globalization has made the correlation among economies (nations) positive and the risk (systemic) high, which make the international portfolia sub-optimal. ${ }^{3}$ Which are backed by their governments' debt; then:

$$
\text { liability }_{G} \text { xliability }_{C B}=\text { liability }^{2} \equiv \text { fiat money (currency). }^{\text {. }}
$$
}




\section{The Efficiency of the Foreign Exchange Market}

The efficient market hypothesis (EMH) has been developed in the domestic finance by Eugene Fama since early 1970. (Fama 1970). In finance, the EMH asserts that financial markets are "informationally efficient". In consequence of this, one cannot consistently achieve returns in excess of average market returns on a risk-adjusted basis, given the publically available information at the time the investment is made. In this efficient market all new information is quickly understood by market participants and becomes immediately incorporated into market prices. Thus, prices of financial assets provide signals for portfolio allocation. Market efficiency is associated with the rationality of market expectations. However, is this "publically available information", given by the controlled media, the markets and governments, the full information that human beings need to maximize their objective functions?

To examine market efficiency, we must determine whether market participants could systematically earn an excess profit. If we designate $R_{t+1}$ as series of asset returns next period and $R_{t+1}^{e}$ as market expectations of these returns and that there are no systematic unexploited profits over time, we can write,

$$
E\left[R_{t+1}-R_{t+1}^{e} \mid \Pi_{t}\right]=0
$$

where, $R_{t+1}=$ the actual return next period, $R_{t+1}^{e}=$ the expected return derived from forecasting it one period ahead, $E=$ is the expectations operator conditioned on the information set $\Pi_{t}$ ( $\Pi=\pi \lambda \eta \rho о \varphi о \rho i \alpha 1$, very broad and completely full information, true knowledge of our destination in life $)^{4}$ available at the end of period t, as Davidson (2015) mentions.

In case that there are systematic forecast errors in $R_{t+1}^{e}$, the information would be incorporated into the forecast process. Investors inspect the forecast errors $\left(R_{t+1}-R_{t+1}^{e}=\varepsilon_{t+1}\right)$ to see whether there are unexploited patters that may be used to improve their investment strategy. Thus, the systematic information will be exploited and the resulting error becomes "white noise". To satisfy the efficiency

\footnotetext{
${ }^{4}$ Unfortunately, this is almost impossible. Of course, there are very few people that they have full information. See, http://www.goodreads.com/author/quotes/9951.David_Rockefeller. David Rockefeller passed away on March 20, 2017 at the age of 101 years old and the controlled media praised him as the greatest philanthropist of our times. See, https://www.nytimes.com/ 2017/03/20/business/david-rockefeller-dead-chase-manhattan-banker.html?_r=0 . See, also the other side, https://thefullertoninformer.com/the-death-of-one-of-the-most-evil-men-in-our-life time-david-rockefeller-enters-the-gates-of-hell-after-101-years/. They are working since 1640 to control the uninformed masses (Goyim) and they succeeded as we see today. Also, "Journalism in America is dead". (Sean Hannity, Fox News, April 26, 2017).

${ }^{5}$ White noise process is a sequence $\left\{\varepsilon_{t}\right\}$ if each value in the sequence has a mean value of zero, a constant variance, and is serially uncorrelated. If the notation $E(R)$ denotes the theoretical mean value of $R$, the sequence $\left\{\varepsilon_{t}\right\}$ is a white-noise process for each time period $t, E\left(\varepsilon_{t}\right)=0$, $E\left(\varepsilon_{t}^{2}\right)=\sigma^{2}$, and $E\left(\varepsilon_{t}, \varepsilon_{t-1}\right)=0$.
} 
condition [eq. (1)], an optimal forecast of asset prices is consistent with rational expectations behavior.

In the foreign exchange markets, the efficient markets hypothesis has been applied to the spot market and to the forward market and our objective, here, is to test this foreign exchange markets efficiency. Equation (1) can be used to express the spot exchange rate as follows:

$$
E\left[s_{t+1}-s_{t+1}^{e} \mid \Pi_{t}\right]=0
$$

where, $s_{t+1}=$ the $\ln$ (natural logarithm) of the spot exchange rate and $s_{t+1}^{e}=$ the $\ln$ of the expected spot rate based on information $\Pi_{t}(=\pi \lambda \eta \rho о \varphi \circ \rho i ́ \alpha)$ available at time $t$.

The above equation [eq. (2)] states that the expectations errors will be zero on average so that, no excess profits can be exploited in the foreign exchange markets. The difficulty is how to form the optimal forecast value that results in residuals displaying no informational content. We can use $A R(p)$ or $M A(q)$ or $\operatorname{ARMA}(p, q)$ processes or a multi-variable one based on economic theory (fundamentals) or a transfer function to forecast $s_{t+1}^{e}$.

\section{The Random Walk Hypothesis}

Let the current value of $s_{t}$ be equal to last period's value plus a white-noise term,

$$
s_{t}=s_{t-1}+\varepsilon_{t}
$$

or

$$
s_{t}-s_{t-1}=\varepsilon_{t}
$$

The random walk model (Enders 1995:166-169) is clearly a special case of the AR (1) process, as follows:

$$
s_{t}=\alpha_{0}+\alpha_{1} s_{t-1}+\varepsilon_{t}
$$

when, $\alpha_{0}=0$ and $\alpha_{1}=1$, the RWH holds.

In practice, the investor does not need all the information in $\Pi_{t}$ that are based on experience, empirical knowledge, market conditions, history, politics, round knowledge, true wisdom, revealed Truth, objective in life, because he will have very high information costs. Then, a rational investor may use a smaller set of information $I_{t}$ to form exchange rate expectations. Economists have observed that the exchange rate follows a random walk process, which means that the expected exchange rate next period $s_{t+1}^{e}$ is equal to the current spot rate $s_{t}$. Thus,

$$
s_{t+1}^{e}=s_{t}
$$


Now, substituting eq. (6) into eq. (2) and using information $I_{t}$, we get:

$$
E\left[s_{t+1}-s_{t} \mid I_{t}\right]=0
$$

This equation (7) suggests that if the foreign exchange market is efficient, the current exchange rate will reflect all the available information and the unexpected change in the spot rate $\left(s_{t+1}-s_{t}\right)$, is essentially caused by the random shock $\varepsilon_{t+1}$, which hits the market between time $t$ and time $t+1$. Market rationality suggests that the investor finds no particular pattern from the history of $\varepsilon_{t+1}$. This random walk (market efficiency) can be tested by using eq. (5). If $\alpha_{0} \cong 0$ and $\alpha_{1} \cong 1$, the foreign exchange market is efficient. This random walk hypothesis explains the erratic behavior of exchange rate movements. Exchange rates respond to "news" (surprises), which are unpredictable. ${ }^{6}$ Thus, exchange rates move randomly because they respond sensitively to the unexpected events that randomly hit the markets.

\section{The Unbiased Forward Rate Hypothesis}

Another way to measure the expected exchange rate is to use the forward exchange rate $\left(f_{t}\right) .^{7}$ The forward rate has been viewed as an unbiased predictor of the future spot rate ("the Unbiased Forward Rate Hypothesis"). The validity of this UFRH implies that: (1) the investor is risk-neutral, (2) transaction costs are insignificant, and (3) the arrival of important informational events is random. This hypothesis is derived from an efficient arbitrage activity by investors and it is expressed as:

$$
s_{t+1}^{e}=f_{t}
$$

Substituting $s_{t+1}^{e}$ in eq. (2) with $f_{t}$ and a smaller information set $I_{t}$ (due to lack of complete information because of its enormous cost and other factors), we have:

$$
E\left[s_{t+1}-f_{t} \mid I_{t}\right]=0
$$

Equation (9) states that the forecast errors resulting from using forward rates to predict the future spot rates will be zero on average. A nonzero value, $E\left[s_{t+1}-f_{t} \mid I_{t}\right] \neq 0$, suggests the rejection of the unbiased forward rate hypothesis, due

\footnotetext{
${ }^{6}$ For example, we saw what happened with the British pound (f), when British voted to a referendum on June 23, 2016 to leave the EU. (http://www.bbc.com/news/uk-politics-32810 887). The pound depreciated by $9 \%$ with respect the U.S. dollar. (http://money.cnn.com/2016/ 06/24/investing/pound-crash-eu-referendum/ ).

${ }^{7}$ A question exists in many economists. Who is setting this forward rates? What is the role of the futures market in our economic system? Why authorities cannot regulate the futures market? The market participants have no choice, but to follow the futures and forward markets; so with their actions, they prove that the forward rate is an unbiased predictor of the future spot rate.
} 
to (1) high transaction costs associated with arbitrage, (2) a risk premium $\left(r p_{t+1}\right)$ if investors are no risk-neutral, and (3) a specification error if the model is not well specified. This UFRH (market efficiency) can be tested as follows:

$$
s_{t}=\alpha_{0}+\alpha_{1} f_{t-1}+\varepsilon_{t}
$$

If $\alpha_{0} \cong 0$ and $\alpha_{1} \cong 1$, the foreign exchange market is efficient; last period's forward rate predicts the current spot rate. Prices reflect all relevant available information; thus, the residuals in eq. (10) should contain no information and, therefore, should be serially uncorrelated $\left[E\left(\varepsilon_{t}, \varepsilon_{t-1}\right)=0\right]$. Further, under the assumption of risk neutrality, if the forward exchange rate is an unbiased predictor of the future spot exchange rate $\left[f_{t}=s_{t+1}\right]$; then, the constant term should be closed to zero $\left[\alpha_{0} \cong 0\right]$ and the slope coefficient (actually, elasticity) should be closed to unity $\left[\alpha_{1} \cong 1\right]$.

Also, if forward exchange rates prevailing at period $t-1$ summarize all relevant information available at that period, these exchange rates should also contain the information that is summarized in data corresponding to period $t-2$ and so on. It follows that including additional lagged values of the forward rates in eq. (10) should not greatly affect the coefficients of determination and the sum of these coefficients must not differ significantly from unity (the inclusion of additional lagged variables does not improve the fit). ${ }^{8}$

$$
s_{t}=\alpha_{0}+\alpha_{1} f_{t-1}+\alpha_{2} f_{t-2}+\varepsilon_{t}
$$

Hence, if $\alpha_{0} \cong 0$ and $\alpha_{1}+\alpha_{2} \cong 1$ the foreign exchange market is efficient; last periods' forward rates predict the current spot rate.

\section{The Composite Efficiency Hypothesis}

The composite efficiency hypothesis $(\mathrm{CEH})$ combines the previous two hypotheses (the random walk and the unbiased forward rate hypotheses). It suggests that the expected future spot exchange rate is a weighted average of the current spot rate and the forward rate, as follows,

$$
s_{t+1}^{e}=w s_{t}+(1-w) f_{t}
$$

where, $w=$ the weight of the spot rate.

Equation (12) is based on the information contained in the spot and forward rates. We assume rational expectations, here, based on Mishkin (1983). The information contained in the spot rate $\left(s_{t}\right)$ reflects current market conditions and summarizes all historical information that affects exchange rates. The forward

\footnotetext{
${ }^{8}$ We can test this eq. (11) by using more lagged values than two and to see its efficiency, if $\alpha_{1}+\alpha_{2}+\alpha_{3}+\ldots \cong 1$.
} 
rate $\left(f_{t}\right)$ reflects all the information concerning factors that are expected to determine future exchange rates. Therefore, the Composite Efficiency Hypothesis $(\mathrm{CEH})$ contains two sets of information affecting the future spot exchange rate; (1) past historical information and (2) rational expectations of the market participants. One problem might still exist: what will be the value of each one of the weights on the spot and forward rates?

The CEH can be tested as follows:

$$
s_{t}=\beta_{0}+\beta_{1} s_{t-1}+\beta_{2} f_{t-1}+\varepsilon_{t}
$$

Then, if $\beta_{0} \cong 0, \beta_{1}=w, \beta_{2}=(1-w)$, and $\beta_{1}+\beta_{2}=w+(1-w) \cong 1$, it means that the foreign exchange market is efficient.

\section{Semi-strong Market Efficiency}

In Semi-strong Form of Market Efficiency, it is implied that share prices adjust to publicly available new information very rapidly and in an unbiased fashion, such that no excess returns can be earned by trading on that information. (Kallianiotis 2013b:72-74). In our case, the information reflected in the current spot exchange rate is more than just the exchange rate history. In addition, the spot exchange rate reflects all publicly available information.

$$
E\left(s_{t+1} \mid I_{P u_{t}}\right)=s_{t}
$$

where, $I_{P u_{t}}=$ the publicly available information in period $t$.

Then, no further information can be gained from public sources that will help to explain the movement of exchange rates. In testing semi-strong efficiency, a formal model to determine the market equilibrium must be chosen and the anticipated (A) or expected (E) and unanticipated (U) components of the exchange rate determinants must be distinguished in order to examine the nature of this form of market efficiency.

$$
s_{t}=E\left(s_{t+1} \mid I_{P u_{t}}\right)+U\left(s_{t+1}\right)
$$

The equilibrium exchange rate may be related to the relative price indexes in the two countries, Purchasing Power Parity (relative PPP) condition. Then, a model that satisfies the efficient markets condition can be the following:

$$
s_{t}=\left[\left(p_{t}-p_{t}^{*}\right)-\left(p_{t}^{e}-p_{t}^{* e}\right)\right] \beta+\varepsilon_{t}
$$

where, $s_{t}=$ the spot exchange rate, $p_{t}=$ a vector containing variables relevant to the domestic price level, $p_{t}^{*}=$ a vector containing variables relevant to the foreign price level, $p_{t}^{e}=$ the vector of the expected domestic price level next period based 
on public information [eq. (14)], $\quad p_{t}^{* e}=$ the vector of the expected foreign price level next period based on all publicly available information [eq. (14)], $\beta=$ vector of coefficients, and $\varepsilon_{t}=$ a disturbance with the property $E\left(\varepsilon_{t} \mid I_{P u_{t}}\right)=0$, thus $\varepsilon_{t}$ is serially uncorrelated with $p_{t}^{e}$ and $p_{t}^{* e}$.

According to the quantity theory (money demand equation), the price level in each country is determined by the money supply, real income, and the interest rate; then, the equilibrium exchange rate is governed by the relative magnitudes of these three variables.

$$
p_{t}=f_{1}\left(m_{t}, y_{t}, i_{t}\right)
$$

and

$$
p_{t}^{*}=f_{2}\left(m_{t}^{*}, y_{t}^{*}, i_{t}^{*}\right)
$$

To test the impact of these exchange rate determinants on the exchange rate in the context of the semi-strong form of the efficiency hypothesis (SSFEH), we divide these determinants into anticipated and unanticipated components, as follows, based on Mishkin (1983).

$$
s_{t}=\alpha+\sum_{j=0}^{n} \beta_{j}\left[\left(p_{t-j}-p_{t-j}^{*}\right)-\left(p_{t-j}^{e}-p_{t-j}^{* e}\right)\right]+\sum_{j=0}^{n} \gamma_{j}\left(p_{t-j}^{e}-p_{t-j}^{*}\right)+\varepsilon_{t}
$$

Since the anticipated components have been observed by the market participants and this information has been incorporated into the determination of the current exchange rate, surprise deviations of the actual spot rate from the market expectations must be associated with the unanticipated components ("news" or innovations) of the three pairs of determinants shown in eqs. (17) and (18).

Some empirical evidence does not find a strong confirmation of the semistrong form of efficiency. The difficulty for this case might have come from the lack of a well-specified model of exchange rate determination or from a wrong procedure of decomposing the relevant variables to anticipated and unanticipated parts.

Foreign Exchange Rate Market Efficiency and Unanticipated Events ("News")

An important characteristic of the rational expectations hypothesis (REH) is that unanticipated events, surprises, and "news" are affecting assets' returns, prices, and real variables in our economies, which are sensitive to information. The recognition, the last half of the century, that expectations are extremely important to the economic decision-making process has led to a major revolution in macroeconomic and financial analysis, but at the same time has increased instability, uncertainty, and dependency on the "news" and markets. The rational expectations hypothesis developed initially by Muth (1961) has played a critical 
role in our market-oriented system and it states that expectations reflected in market behavior will be optimal forecasts using all available information $\left.\left(I_{P_{u_{t}}+\mathrm{Pr}_{t}}\right)\right)^{9}$ In the context of exchange rate determination, it is emphasized that the predominant cause of exchange rate movements are the unanticipated "news" (surprises), as Dornbusch (1978), Bilson (1978), Frenkel and Mussa (1980), Isard (1980), and Frenkel (1984) were using.

$$
s_{t}=" \text { the exp ected exchange rate }{ }_{t} "+" \text { the un exp ected part of the exchange rate }{ }_{t} "
$$

or

$$
s_{t}=s_{t}^{e}+s_{t}^{u}
$$

As it was mentioned above, the forward exchange rate summarizes the information that is available to the market when this forward rate is being set $\left[f_{t}=E\left(s_{t+1} \mid I_{t}\right)\right]$. Therefore, the spot rate can be expressed as a function of factors, which have been known in advance and are summarized by the lagged forward rate plus a function of the "news" and a serially uncorrelated error term, as follows:

$$
s_{t}=\alpha_{0}+\alpha_{1} f_{t-1}+\alpha_{2} " \text { News" }_{t}+\varepsilon_{t}
$$

where, "News" ${ }_{t}=$ variables used in measuring the "news".

Equation (21) can be applied to an empirical analysis of the role of unanticipated events "news" as a determinant of the spot exchange rate. The difficulty is in identifying the variables, which can be used in measuring the "news". Important variables that are affecting the exchange rate can be the interest rates in the two countries because they are market determined and "news" is affecting them promptly. Then, by making the assumption that the (financial) asset market clears fast and that the "news" is immediately reflected in unexpected changes in the interest rates, eq. (21) can be rewritten with an extra term, which represents the surprise between the interest differential and the expected interest differential between the two countries.

$$
s_{t}=\alpha_{0}+\alpha_{1} f_{t-1}+\alpha_{2}\left[\left(i_{t}-i_{t}^{*}\right)-E_{t-1}\left(i_{t}-i_{t}^{*}\right)\right]+\varepsilon_{t}
$$

where, $\alpha_{0}+\alpha_{1} f_{t-1}=$ the expected exchange rate, $\alpha_{2}\left[\left(i_{t}-i_{t}^{*}\right)-E_{t-1}\left(i_{t}-i_{t}^{*}\right)\right]=$ the unexpected (the innovation) part of the exchange rate ("news"), $\left(i_{t}-i_{t}^{*}\right)=$ the actual interest differential in the two countries, and $E_{t-1}\left(i_{t}-i_{t}^{*}\right)=$ the expected interest differential based on information available in period $t-1$.

By taking into consideration the most important relationship in international finance, the interest rate parity (IRP), the expected interest differential can be

\footnotetext{
${ }^{9}$ Where, $\boldsymbol{I}_{P u_{t}+\mathrm{Pr}_{t}}=$ the publically and privately available information in period $\mathrm{t}$.
} 
computed (forecasted) from a regression by using lagged values of the spot and forward rates, and lagged values of the interest differential, as follows,

$$
E_{t-1}\left(i_{t}-i_{t}^{*}\right) \equiv\left(i_{t}-i_{t}^{*}\right)=\beta_{0}+\beta_{1} s_{t-1}+\beta_{2} s_{t-2}+\beta_{3} f_{t-2}+\beta_{4} f_{t-3}+\beta_{5}\left(i_{t-1}-i_{t-1}^{*}\right)+\beta_{6}\left(i_{t-2}-i_{t-2}^{*}\right)+\varepsilon_{t}
$$

Now, we take the difference between the actual interest differential minus the computed expected interest differential, which represents the "news". These two values are used in eq. (22); and by running this regression, the computer will give its coefficients. If $\alpha_{0} \cong \alpha_{2} \cong 0$ and $\alpha_{1} \cong 1$, the foreign exchange market is efficient. In the case that $\alpha_{2} \neq 0$, this means that the current exchange rate is affected by expectations concerning the future course of events and that the unanticipated changes in the exchange rate are primarily due to innovations. Most of the actual changes in exchange rates are unanticipated, which means that most of the actual changes in exchange rates are due to "news".

\section{Exchange Rate Risk Premium and its Determination}

In case there are risk premia $\left(r p_{t+1}=s_{t+1}-f_{t}\right)$, due to an inefficient arbitrage activity, we would like to determine the factors that cause this inefficiency. Some researchers [(Kallianiotis (2013a:107-114) and Giovannini and Jorion (1987)] have related the expected and realized return in the foreign exchange markets to the nominal interest rates (monetary policy target rates and IRP condition) as follows:

$$
s_{t+1}-s_{t}-\left(i_{t}-i_{t}^{*}\right)=\gamma_{0}+\gamma_{1} i_{t}+\gamma_{2} i_{t}^{*}+\varepsilon_{t+1}
$$

where, $\gamma_{1}<0, \gamma_{2}>0, s_{t}-\left(i_{t}-i_{t}^{*}\right)=f_{t}$ is the covered interest rate parity condition, and if $s_{t+1}-f_{t} \neq 0$ this is the exchange rate risk premium $\left(r p_{t+1}\right)$, which shows foreign exchange market inefficiency.

The forecasting of the expected spot exchange rate $\left(s_{t+1}^{e}\right)$ can be done by using an ARMA $(p, q)$ process or the following related to IRP equation:

$$
s_{t}=\xi_{0}+\xi_{1} s_{t-1}+\xi_{2} s_{t-2}+\xi_{3} f_{t-1}+\xi_{4} f_{t-2}+\xi_{5} i_{t-1}+\xi_{6} i_{t-2}+\xi_{7} i_{t-1}^{*}+\xi_{8} i_{t-2}^{*}+\varepsilon_{t}
$$

Now, we know the coefficients $\left(\bar{\xi}_{s}\right)$ and updating one period the variables of the above eq. (25), we receive the $E_{t} s_{t+1}$ conditional on the information available at period $t$.

We can determine the risk premium $\left(r p_{t+1}\right)$ in eq. (24) if it exists (if it is statistically significant) by using a multivariate GARCH-in-Mean (GARCH-M) model, as Engle, Lilien and Robins (1987) and Smith, Soresen and Wickens (2003) were using. We can begin with the simplest GARCH $(1,1)$ specification or a higher order GARCH model, GARCH (q, p), can be estimated by choosing either $\mathrm{q}$ or $\mathrm{p}$ greater than 1 , where $\mathrm{q}$ is the order of the autoregressive GARCH 
terms and $\mathrm{p}$ is the order of the moving average ARCH terms. The GARCH ( $\mathrm{q}$, p) variance is:

$$
\sigma_{t}^{2}=\omega+\sum_{j=1}^{q} \beta_{j} \sigma_{t-j}^{2}+\sum_{i=1}^{p} \alpha_{i} \varepsilon_{t-i}^{2}
$$

The $X^{\prime}{ }_{t}$ in eq. (27) represent exogenous or pre-determined macro-variables from both countries included in the mean equation. By introducing the conditional variance into the mean equation, we get the GARCH-in Mean (GARCH-M), ${ }^{10}$ as follows:

$$
r p_{t}=X_{t}^{\prime} \theta+\lambda \sigma_{t}^{2}+\varepsilon_{t}
$$

The mean equation (27) is written as a function of exogenous macro-variables $\left(X_{t}^{\prime}\right)$ from both countries [i. e., eq. (24)] with an error term $\varepsilon_{t}$. Since $\sigma_{t}^{2}$ is the one-period ahead forecast variance based on current information, it is the conditional variance. This conditional variance specified in eq. (26) is a function of three terms: The constant term $\omega$; the current period's forecast variance $\sigma_{t}^{2}$ (the GARCH term), and news about volatility from the previous period, measured as the squared residual from the mean equation $\varepsilon_{t}^{2}$ (the $\mathrm{ARCH}$ term).

Then, we can see if the volatility of the exchange rate $\left(r p_{t+1}\right)$ depends on the forecasted variance $\sigma_{t}^{2}(\mathrm{GARCH})$ or on the residual $\varepsilon_{t}^{2}(\mathrm{ARCH})$ or on the exogenous macro-variables $\left(x_{t}^{\prime}\right)$ or it is insignificant, which proves foreign exchange market efficiency.

\section{Empirical Results}

The data are monthly from Economagic.com, Eurostat, and Bloomberg. For the euro $(€)$, the data are from 1999:01 to 2017:01 and for the other four currencies (\$, £, C\$, and $¥$ ) from 1971:01 to 2017:01. Other data used, here, are T-Bill rates, money supplies, incomes, and price levels. An empirical test of efficiency is a joint test of efficiency (full information) and the equilibrium (harmony) model. By "equilibrium," we mean an internal, external, eternal, and global balance that must exist in markets and societies because we (every individual) must be in balance and live in harmony with ourselves, the others, and the entire socio-economic environment (Kallianiotis 2017b, 2016a); otherwise, how can there be an equilibrium? Recent tests conducted by Kallianiotis (2016b) show that the evidence supporting the unbiased forward rate hypothesis is quite weak. $\mathrm{He}$

\footnotetext{
${ }^{10}$ The GARCH-M model is often used in financial applications where the expected return on an asset is related to the expected asset risk. The estimated coefficient on the expected risk is a measure of the risk-return tradeoff.
} 
found that a non-consistent risk premium is present in several major foreign exchange markets $(\$ / €, \$ / £$, and $¥ / \$)$. The implication of these empirical findings is that one cannot use the forward rate directly as a measure for the future spot rate because there are many interventions in the foreign exchange market.

The objective, here, is to provide some evidence concerning the theories of exchange rate determination and market efficiency. Least squares regression analyses are used, which provides a method for fitting the mathematical functions discussed in theory above to observed data. In case of inefficiency, a risk premium exists and it is determined by using a GARCH-M model. Also, testing of the different hypotheses, correlations, pairwise Granger causality tests, GARCH methods of measuring volatility (variance) of exchange rate risk premium $\left(r p_{t}\right)$ and the static and dynamic forecasting of the $r p_{t+1}^{e}$ are presented in tables and graphically to help us understand the theories and observe and measure the efficiency of the foreign exchange markets.

We start with the random walk (market efficiency), which is presented in Table 1. Between the U.S. dollar and euro $(\$ / €)$, the results show, $\alpha_{0} \cong 0$ (statistically insignificant) and $\alpha_{1}=0.987 \cong 1$ (statistically significant at the $1 \%$ level); thus, the market for this $s_{t}$ is efficient. Then, between the U.S. dollar and British pound $(\$ / \mathfrak{E})$ the results are, $\alpha_{0} \cong 0$ (statistically insignificant) and $\alpha_{1}=0.990 \cong 1$ (statistically significant at the $1 \%$ level); thus, the market for this $S_{t}$ is efficient for this long period (from 1971:02 to 2017:01). Now, the test between the Canadian dollar and the U.S. dollar (C\$ $\$$ ) shows, $\alpha_{0} \neq 0$ (statistically significant at the $10 \%$ level) and $\alpha_{1}=0.993 \cong 1$ (statistically significant at the $1 \%$ level); then, the market for spot

Table 1. Testing for Random Walk, Eq. (5)

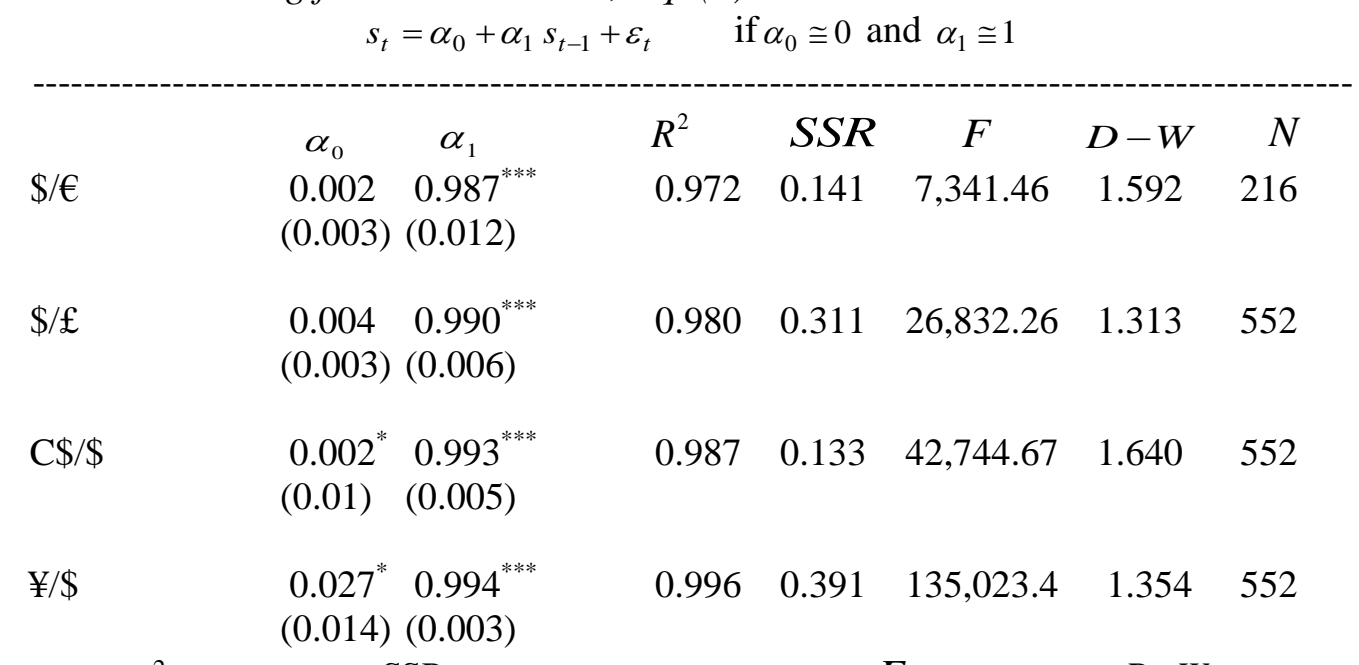

Note: $R^{2}=$ R-squared, $S S R=$ sum of squared residuals, $F=$ F-Statistic, $D-W=$ DurbinWatson Statistic, $N=$ number of observations, ${ }^{* * *}=$ significant at the $1 \%$ level, ${ }^{* *}=$ significant at the $5 \%$ level, and ${ }^{*}=$ significant at the $10 \%$ level. Source: Economagic.com, Bloomberg, and Eurostat. 
$(\mathrm{C} \$ \$)$ exchange rate is not very efficient. Lastly, the market efficiency between the Japanese yen and the U.S. dollar $(¥ / \$)$ is tested and gives, $\alpha_{0} \neq 0$ (statistically significant at the $10 \%$ level) and $\alpha_{1}=0.994 \cong 1$ (statistically significant at the $1 \%$ level); consequently, the market for this $s_{t}$ is not very efficient.

Also, the UFRH is tested with eq. (10) and is presented in Table 2a. For the U.S. dollar and euro, the results are as follows, $\alpha_{0}=0.007 \cong 0$ (statistically insignificant) and $\alpha_{1}=0.965 \cong 1$ (statistically significant at the $1 \%$ level); then, the foreign exchange market for $(\$ / €)$ exchange rate is efficient and the forward rate is an unbiased predictor of the future spot rate. Further, the UFRH for the U.S. dollar and British pound gives $\alpha_{0} \cong 0.012$ (statistically significant at the $5 \%$ level) and $\alpha_{1}=0.972 \cong 1$ (statistically significant at the $1 \%$ level), which shows that the foreign exchange market for $(\$ / \mathfrak{f})$ exchange rate is relatively efficient. In addition, the UFRH for the Canadian dollar and the U.S. dollar $(\mathrm{C} \$ / \$)$ gives $\alpha_{0}=0.001$ (statistically insignificant) and $\alpha_{1}=0.997 \cong 1$ (statistically significant at the $1 \%$ level); then, this market is efficient. Likewise, the UFRH for the Japanese yen and the U.S. dollar is as follows: The $\alpha_{0} \cong 0.099$ (statistically significant at the $1 \%$ level) and $\alpha_{1}=0.979 \cong 1$ (statistically significant at the $1 \%$ level); thus, the foreign exchange market for (¥/\$) exchange rate is inefficient.

Besides, the UFRH is also tested with eq. (11) and the results are given in Table $2 \mathrm{~b}$. For the exchange rate between the U.S. dollar and the euro, it is as follows, $\alpha_{0} \cong 0$ (statistically insignificant) and $\alpha_{1}+\alpha_{2}=1.004-0.042=0.962 \cong 1$ (with $\alpha_{1}$ statistically significant at the $1 \%$ level); then, this foreign exchange market is efficient. For the U.S. dollar and the British pound, the results are: $\alpha_{0} \cong 0.014$ (statistically significant at the $1 \%$ level) and $\alpha_{1}+\alpha_{2}=1.054-0.085=0.969 \cong 1$ (with $\alpha_{1}$ statistically significant at the $1 \%$ level and $\alpha_{2}$ at the $5 \%$ level); then, this foreign exchange market is relatively efficient. Also, the UFRH for the Canadian dollar and the U.S. dollar gives $\alpha_{0}=0.001$ (statistically insignificant) and $\alpha_{1}+\alpha_{2}=0.926+0.072 \cong 1$ (with $\alpha_{1}$ statistically significant at the $1 \%$ level and $\alpha_{2}$ at the $10 \%$ level), which show market efficiency. Finally, the UFRH is tested for the Japanese yen and the 
Table 2a. Testing for the Unbiased Forward Rate Hypothesis (UFRH), Eq. (10)

\begin{tabular}{|c|c|c|c|c|c|c|c|}
\hline & $\alpha_{0}$ & $\alpha_{1}$ & $R^{2}$ & $S S R$ & $F$ & $D-W$ & $N$ \\
\hline$\$ / €$ & $\begin{array}{c}0.007 \\
(0.006)\end{array}$ & $\begin{array}{l}0.965^{* * *} \\
(0.021)\end{array}$ & 0.937 & 0.072 & $2,026.84$ & 1.677 & 139 \\
\hline$\$ / £$ & $\begin{array}{c}0.012^{*} \\
(0.005)\end{array}$ & $\begin{array}{l}0.972^{* * *} \\
(0.010)\end{array}$ & 0.968 & 0.083 & $9,445.43$ & 1.758 & 315 \\
\hline $\mathrm{C} \$ / \$$ & $\begin{array}{r}0.001 \\
(0.01)\end{array}$ & $\begin{array}{l}0.997^{* * * *} \\
(0.007)\end{array}$ & 0.989 & 0.068 & $20,971.28$ & 2.086 & 240 \\
\hline$¥ / \$$ & $\begin{array}{c}0.099^{*} \\
(0.033)\end{array}$ & $\begin{array}{c}{ }^{* *} 0.979^{* * * *} \\
(0.007)\end{array}$ & 0.984 & 0.019 & $19,529.22$ & 1.795 & 315 \\
\hline
\end{tabular}

Note: See, Table 1.

Source: See, Table 1.

Table 2b. Testing for the Unbiased Forward Rate Hypothesis (UFRH), Eq. (11)

$$
s_{t}=\alpha_{0}+\alpha_{1} f_{t-1}+\alpha_{2} f_{t-2}+\varepsilon_{t} \quad \text { if } \alpha_{0} \cong 0 \text { and } \alpha_{1}+\alpha_{2} \cong 1
$$

$\begin{array}{lllllllll} & \alpha_{0} & \alpha_{1} & \alpha_{2} & R^{2} & S S R & F & D-W & N \\ \$ / € & 0.008 & 1.004^{* * *}-0.042 & 0.937 & 0.072 & 1,002.25 & 1.728 & 138 \\ & (0.006) & (0.066) & (0.066) & & & & & \\ \$ / £ & 0.014^{* * *} & 1.054^{* * *}-0.085^{* *} & 0.969 & 0.016 & 4,795.29 & 1.974 & 314 \\ & (0.005) & (0.034) & (0.035) & & & & \\ \mathrm{C} \$ / \$ & 0.001 & 0.926^{* * *} & 0.072^{*} & 0.989 & 0.067 & 10,514.91 & 1.883 & 239 \\ & (0.002) & (0.043) & (0.043) & & & & & \\ ¥ / \$ & 0.106^{* * *} 1.045^{* * *} & -0.067^{*} & 0.984 & 0.111 & 9,725.57 & 2.001 & 314 \\ & (0.033) & (0.035) & (0.035) & & & & \end{array}$

Note: See, Table 1.

Source: See, table 1.

U.S. dollar, which gives $\alpha_{0} \cong 0.106$ (statistically significant at the $1 \%$ level) and $\alpha_{1}+\alpha_{2}=1.045-0.067=0.978 \cong 1$ (with $\alpha_{1}$ statistically significant at the $1 \%$ level and $\alpha_{2}$ at the $10 \%$ level). Then, this foreign exchange market ( $\left.¥ / \$\right)$ is relatively efficient.

Further, the composite efficiency, eq. (13), is presented in Table 3. For the U.S. dollar and euro the results are $\beta_{0} \cong 0$ (statistically insignificant) and $\beta_{1}+\beta_{2}=0.199+0.772=0.971 \cong 1$ (with $\beta_{2}$ statistically significant at the $1 \%$ level); then, the composite efficiency holds, but only the forward rate contributes to the future spot rate. Now, the composite efficiency for the U.S. dollar and 
British pound gives the results: $\beta_{0} \cong 0.014$ (statistically significant at the $1 \%$ level) and $\beta_{1}+\beta_{2}=-0.133+1.101=0.968 \cong 1$ (with $\beta_{1}$ statistically significant at the $5 \%$ level and $\beta_{2}$ statistically significant at the $1 \%$ level); consequently, the composite efficiency relatively holds and both spot and forward rates contribute to the future spot rate. Further, the composite efficiency for the Canadian dollar and the U.S. dollar gives $\beta_{0}=0.001$ (statistically insignificant) and $\beta_{1}+\beta_{2}=0.158+0.839=0.997 \cong 1$ (with $\beta_{1}$ statistically significant at the $5 \%$ level and $\beta_{2}$ statistically significant at the $1 \%$ level); thus, the market for $\mathrm{C} \$ / \$$ is composite efficient. Lastly, the composite efficiency for the Japanese yen and the U.S. dollar is tested and the results are $\beta_{0}=0.105$ (statistically significant at the $1 \%$ level) and $\beta_{1}+\beta_{2}=-0.099+1.076=0.977 \cong 1$ (with $\beta_{1}$ statistically insignificant and $\beta_{2}$ statistically significant at the $1 \%$ level); thus, the composite efficiency relatively holds, but only the forward rate contributes to the future spot rate.

Table 3. The Composite Efficiency, Eq. (13)

\begin{tabular}{|c|c|c|c|c|c|c|c|c|}
\hline & $\beta_{0}$ & $\beta_{1}$ & $\beta_{2}$ & $R^{2}$ & $S S R$ & $F$ & $D-W$ & $N$ \\
\hline$\$ / €$ & $\begin{array}{c}0.006 \\
(0.006)\end{array}$ & $\begin{array}{l}0.199 \quad 0 \\
(0.124)\end{array}$ & $\begin{array}{c}0.772^{* * * *} \\
(0.122)\end{array}$ & 0.938 & 0.071 & $1,026.33$ & 1.671 & 139 \\
\hline$\$ / £$ & $\begin{array}{c}0.014^{* * *} \\
(0.005)\end{array}$ & $\begin{array}{c}-0.133^{* *} \\
(0.065)\end{array}$ & $\begin{array}{l}1.101^{* * *} \\
(0.064)\end{array}$ & 0.968 & 0.082 & $4,773.36$ & 1.869 & 315 \\
\hline $\mathrm{C} \$ / \$$ & $\begin{array}{c}0.001 \\
(0.002)(0\end{array}$ & $\begin{array}{l}0.158^{* *} \\
0.074)\end{array}$ & $\begin{array}{c}0.839^{* * * *} \\
(0.075)\end{array}$ & 0.989 & 0.067 & $10,642.66$ & 1.983 & 240 \\
\hline$¥ / \$$ & $\begin{array}{l}0.105^{* * *} \\
(0.033)\end{array}$ & $\begin{array}{c}-0.099 \\
(0.065)\end{array}$ & $\begin{array}{l}1.076^{* * *} \\
(0.064)\end{array}$ & 0.984 & 0.112 & $9,807.26$ & 1.885 & 315 \\
\hline
\end{tabular}

Note: See, Table 1.

Source: See, Table 1.

Furthermore, Table 4a shows the estimation of the forecasting price level in the five economies ( $p_{t}^{e}$ for the U.S.) and ( $p_{t}^{* e}$ for the foreign countries), eqs. (17) and (18). These expected price levels are used in eq. (19) to determine the Semi-strong Form of the Efficiency Hypothesis (SSFEH). The results appeared in table $4 \mathrm{~b}$. The $\$ / €$ exchange rate shows that the unanticipated component has a significant effect $\left(\gamma=5.832^{* * * * *}\right)$ on $s_{t}$, but correcting for serial correlation, there is no effect on the spot rate by the anticipated or the unanticipated components. For the $s_{t}(\$ / \mathscr{f})$, there is significant effect $\left(\gamma=0.894^{* * * * *}\right)$ from the unanticipated price level differential and by correcting the serial correlation, there is a small effect $\left(\gamma=0.535^{*}\right)$ from the unanticipated component. Then, looking at the $s_{t}(\mathrm{C} \$ / \$)$, there is a significant effect $\left(\gamma=-0.949^{\text {*wak }}\right)$ from the 
unanticipated component; but correcting for serial correlation, we see that neither anticipated nor unanticipated component have an effect on spot rate. Lastly, observing the $s_{t}(¥ / \$)$, we see significant $\left(\gamma=-0.414^{* * * *}\right)$ effect of the unanticipated component and after the correction for serial correlation, there is no effect on the spot rate. The conclusion is here that investors have interpreted the information $\left(I_{P u_{t}}\right)$ in an unbiased fashion, which implies semi-strong Form Efficiency for $\$ / €$ and $C \$ / \$$ holds, following by $\$ / £\left(\gamma=0.535^{*}\right)$ and $¥ / \$$ $\left(\alpha=4.622^{* * * *}\right)$ exchange rates that show some kind of inefficiency.

Table 4a. Estimation of the $p_{t}^{e}$ and $p_{t}^{* e}$, Eqs. (17) and (18)

$$
p_{t}=\alpha_{0}+\alpha_{1} m_{t}+\alpha_{2} y_{t}+\alpha_{3} i_{t}+\varepsilon_{t}
$$

\begin{tabular}{|c|c|c|c|c|c|}
\hline & $p_{t}^{U S}$ & $p_{t}^{E U}$ & $p_{t}^{C}$ & $p_{t}^{U K}$ & $p_{t}^{J}$ \\
\hline$\alpha_{0}$ & $\begin{array}{r}2.960 \\
(2.965)\end{array}$ & $\begin{array}{l}2.337^{* * *} \\
(0.300)\end{array}$ & $\begin{array}{l}3.869^{* * *} \\
(1.147)\end{array}$ & $\begin{array}{l}8.204^{* * *} \\
(0.251)\end{array}$ & $\begin{array}{l}6.675^{* * *} \\
(0.644)\end{array}$ \\
\hline$\alpha_{1}$ & $\begin{array}{c}0.136^{* * *} \\
(0.025)\end{array}$ & $\begin{array}{l}0.307^{* * * *} \\
(0.013)\end{array}$ & $\begin{array}{c}0.010 \\
(0.008)\end{array}$ & $\begin{array}{c}0.150^{* * *} \\
(0.009)\end{array}$ & $\begin{array}{l}-0.009 \\
(0.045)\end{array}$ \\
\hline$\alpha_{2}$ & $\begin{array}{l}0.060^{* * *} \\
(0.022)\end{array}$ & $\begin{array}{l}-0.053 \\
(0.051)\end{array}$ & $\begin{array}{l}0.065^{* * *} \\
(0.021)\end{array}$ & $\begin{array}{l}-0.570^{* * *} \\
(0.014)\end{array}$ & $\begin{array}{l}-0.228^{* * *} \\
(0.012)\end{array}$ \\
\hline$\alpha_{3}$ & $\begin{array}{l}0.001^{* *} \\
(0.001)\end{array}$ & $\begin{array}{l}-0.001 \\
(0.001)\end{array}$ & $\begin{array}{l}-0.001 \\
(0.001)\end{array}$ & $\begin{array}{l}-0.001 \\
(0.001)\end{array}$ & $\begin{array}{c}0.001 \\
(0.001)\end{array}$ \\
\hline$A R(1)$ & $\begin{array}{l}0.999^{\text {**** }} \\
(0.002)\end{array}$ & $\begin{array}{l}0.754^{* * *} \\
(0.056)\end{array}$ & $\begin{array}{l}0.999^{* * *} \\
(0.002)\end{array}$ & $\begin{array}{l}0.999^{* * *} \\
(0.002)\end{array}$ & $\begin{array}{l}0.967^{* * *} \\
(0.020)\end{array}$ \\
\hline$M A(1)$ & $\begin{array}{l}0.534^{* * *} \\
(0.030)\end{array}$ & $\begin{array}{c}0.290^{* *} \\
(0.118)\end{array}$ & $\begin{array}{l}0.286^{* * *} \\
(0.042)\end{array}$ & - & $\begin{array}{l}0.253^{* * *} \\
(0.077)\end{array}$ \\
\hline$R^{2}$ & 0.999 & 0.998 & 0.999 & 0.999 & 0.953 \\
\hline$S S R$ & 0.007 & 0.001 & 0.007 & 0.003 & 0.002 \\
\hline$F$ & $1,894,299$ & $10,600.73$ & $276,983.5$ & 169,419 & 841.965 \\
\hline$D-W$ & 1.565 & 1.962 & 1.891 & 1.876 & 2.029 \\
\hline$N$ & 552 & 132 & 428 & 312 & 258 \\
\hline$R M S$ & $E 0.028481$ & 0.002734 & 0.004015 & 0.003064 & 0.002898 \\
\hline
\end{tabular}

Note: See, Table 1.

Source: See, Table 1. 
Table 4b. The Semi-strong Form of Efficiency Hypothesis, Eq. (19)

\begin{tabular}{|c|c|c|c|c|c|c|c|c|c|c|}
\hline & $\alpha$ & $\beta$ & $\gamma$ & $A R(1)$ & $M A(1)$ & $R^{2}$ & $S S R$ & $F$ & $D-W$ & $N$ \\
\hline$\$ / €$ & $\begin{array}{l}-3.760^{*} \\
(0.697)\end{array}$ & $\begin{array}{c}8.039^{*} \\
(4.124)\end{array}$ & $\begin{array}{l}5.832^{* * m} \\
(0.122)\end{array}$ & - & - & 0.249 & 1.413 & 15.137 & 0.077 & 96 \\
\hline$\$ / €$ & $\begin{array}{l}-0.285 \\
(0.657)\end{array}$ & $\begin{array}{l}0.456 \\
(0.829)\end{array}$ & $\begin{array}{l}0.648 \\
(0.958)\end{array}$ & $\begin{array}{l}0.974^{* * *} \\
(0.023)\end{array}$ & $\begin{array}{l}0.381^{* * * *} 0 \\
(0.106)\end{array}$ & 0.973 & 0.050 & 660.095 & 1.949 & 96 \\
\hline$\$ / £$ & $\begin{array}{l}-0.176^{*} \\
(0.090)\end{array}$ & $\begin{array}{r}2.896^{* *} \\
(1.141)\end{array}$ & $\begin{array}{l}0.894^{* * *} \\
)(0.120)\end{array}$ & - & - & 0.1682 & 2.097 & 31.044 & 0.104 & 311 \\
\hline$\$ / £$ & $\begin{array}{l}0.092 \\
(0.200)(\end{array}$ & $\begin{array}{c}0.312 \\
(0.228)\end{array}$ & $\begin{array}{c}0.535^{*} \\
(0.270)\end{array}$ & $\begin{array}{l}0.940^{* * * *} \\
(0.018)\end{array}$ & $\begin{array}{l}0.367^{* * * *} \\
(0.049)\end{array}$ & 0.9450 & 0.1371 , & $1,057.819$ & 1.995 & 311 \\
\hline $\mathrm{C} \$ / \$$ & $\begin{array}{l}0.770^{* * *} \\
(0.073)(\end{array}$ & $\begin{array}{ll}-1.621 & - \\
(1.647) & ((\end{array}$ & $\begin{array}{l}-0.949^{* * *} \\
(0.127)\end{array}$ & - & - & 0.1186 & 6.135 & 28.344 & 0.022 & 427 \\
\hline $\mathrm{C} \$ / \$$ & $\begin{array}{l}0.303 \\
(0.241)\end{array}$ & $\begin{array}{l}-0.231 \\
(0.290)\end{array}$ & $\begin{array}{l}-0.133 \\
(0.375)\end{array}$ & $\begin{array}{l}0.987^{* * * *} \\
(0.007)\end{array}$ & $\begin{array}{l}0.162^{* * * *} \\
(0.031)\end{array}$ & 0.983 & 30.118 & $\begin{array}{ll}8 & 4,884.87\end{array}$ & $\begin{array}{ll}76 & 1.973\end{array}$ & $\begin{array}{ll}3 \quad 427 \\
\end{array}$ \\
\hline$¥ / \$$ & $\begin{array}{l}4.936^{* * * *} \\
(0.035)\end{array}$ & $\begin{array}{l}-3.846^{*} \\
(2.030)\end{array}$ & $\begin{array}{l}-0.414^{* * * *} \\
(0.053)\end{array}$ & - & - & 0.202 & 24.139 & 32.182 & 0.067 & 257 \\
\hline$¥ / \$$ & $\begin{array}{l}4.622^{* * *} \\
(0.255)\end{array}$ & $\begin{array}{l}-0.121 \\
(0.354)\end{array}$ & $\begin{array}{c}0.084 \\
(0.372)\end{array}$ & $\begin{array}{l}0.975^{* * *} \\
(0.014)\end{array}$ & $\begin{array}{c}0.273^{* * * *} \\
(0.050)\end{array}$ & 0.969 & 9.160 & $1,579.18$ & 81.931 & 257 \\
\hline
\end{tabular}

Note: See, Table 1.

Source: See, Table 1.

In addition, Table 5a gives the forecasts of the expected interest rate differential between the U.S. and the other countries, eq. (23). Then, Table 5b presents the tests of the exchange rate expectations and the "news", eq. (22). We start, first, running eq. (23) between U.S. and EMU (\$/€) to forecast the $E_{t-1}\left(i_{t}-i_{t}^{*}\right)$. We generate, $I D 1_{t}=\left(i_{t}-i_{t}^{*}\right)$ and the results of this regression are presented in Table 5a. The computer is giving to us the $I D 1 F_{t} \equiv E_{t-1} I D 1_{t}=E_{t-1}\left(i_{t}-i_{t}^{*}\right)$ from the above equation. With this forecasting interest differential, $I D 1 F_{t}$, we run eq. (22) and the results shows that $\alpha_{0} \cong \alpha_{2} \cong 0$ (statistically insignificant both coefficients) and $\alpha_{1}=0.976 \cong 1$ (statistically significant at the $1 \%$ level). Thus, the exchange rate market for $(\$ / €)$ is efficient and the unanticipated events ("news") have no effect on spot exchange rate (they are anticipated). We continue with U.S. and U.K. (\$/£), running eq. (23) to forecast the $E_{t-1}\left(i_{t}-i_{t}^{*}\right)$ and the results of this regression are given in table $5 \mathrm{a}$. 
Table 5a. The Expected Interest Differential, Eq. (23)

\begin{tabular}{|c|c|c|c|c|}
\hline & ID1 $(\$ / €)$ & ID2 (\$/£) & ID3 $(\mathrm{C} \$ / \$)$ & ID4 (¥/\$) \\
\hline \multirow[t]{2}{*}{$\beta_{0}$} & $0.175^{* * *}$ & 0.003 & -0.020 & $0.703^{*}$ \\
\hline & $(0.060)$ & $(0.086)$ & $(0.021)$ & $(0.417)$ \\
\hline \multirow[t]{2}{*}{$s_{t-1}$} & 0.190 & $-2.533^{* * *}$ & 0.552 & $-0.991^{*}$ \\
\hline & $(0.797)$ & $(0.942)$ & $(0.685)$ & $(0.592)$ \\
\hline \multirow{2}{*}{$s_{t-2}$} & 0.819 & 1.833 & 0.413 & 0.791 \\
\hline & (1.560) & (1.929) & $(1.260)$ & (1.226) \\
\hline \multirow[t]{2}{*}{$f_{t-2}$} & -0.346 & 1.178 & -0.557 & 0.597 \\
\hline & $(1.270)$ & (1.532) & (1.012) & $(0.965)$ \\
\hline \multirow[t]{2}{*}{$f_{t-3}$} & $-1.482^{*}$ & -0.538 & -0.429 & -0.550 \\
\hline & $(0.829)$ & (1.039) & $(0.720)$ & $(0.658)$ \\
\hline \multirow[t]{2}{*}{$i_{t-1}-i_{t-1}^{*}$} & $0.924^{* * * *}$ & $1.149^{* * * *}$ & $0.881^{* * * *}$ & $1.353^{* * *}$ \\
\hline & $(0.086)$ & $(0.059)$ & $(0.066)$ & $(0.061)$ \\
\hline \multirow[t]{2}{*}{$i_{t-2}-i_{t-2}^{*}$} & -0.065 & $-0.175^{* * *}$ & 0.075 & $-0.352^{* * *}$ \\
\hline & $(0.086)$ & $(0.058)$ & $(0.065)$ & $(0.061)$ \\
\hline$R^{2}$ & 0.879 & 0.977 & 0.952 & 0.993 \\
\hline$S S R$ & 5.797 & 20.226 & 7.110 & 7.827 \\
\hline$F$ & 161.645 & $2,185.208$ & 750.066 & $6,071.753$ \\
\hline$D-W$ & 1.967 & 1.990 & 1.963 & 2.042 \\
\hline$N$ & 140 & 312 & 235 & 259 \\
\hline RMSE & 0.203479 & 0.254614 & 0.173938 & 0.1703838 \\
\hline
\end{tabular}

Note: See, Table 1. ID = interest differential.

Source: See, Table 1.

The computer is giving us the $I D 2 F_{t} \equiv E_{t-1} I D 2_{t}=E_{t-1}\left(i_{t}-i_{t}^{*}\right)$ from the above equation. With this forecasting interest differential, $I D 2 F_{t}$, we run eq. (22) and the results show that $\alpha_{0} \neq \alpha_{2} \neq 0$ (statistically significant at $5 \%$ and $1 \%$ level); then, different than zero both coefficients and $\alpha_{1}=0.972 \cong 1$ (statistically significant at the $1 \%$ level). Thus, the exchange rate market for $(\$ / £)$ is inefficient and the changes in this exchange rate are unanticipated (depend on "news"). Also, we forecast the $I D 3 F_{t} \equiv E_{t-1} I D 3_{t}=E_{t-1}\left(i_{t}-i_{t}^{*}\right)$ for the U.S. and Canada $(\mathrm{C} \$ / \$)$ and it presented in Table 5a. Eq. (22), in Table 5b shows that $\alpha_{0} \cong \alpha_{2} \cong 0$ (statistically insignificant) and $\alpha_{1}=0.997 \cong 1$ (statistically significant at the $1 \%$ level). Then, the exchange rate market for $\mathrm{C} \$ / \$$ is efficient and changes in interest rates are anticipated and have no effect on spot exchange rate. Now, we continue with U.S. and Japan (¥/\$), running eq. (23) to forecast the $E_{t-1}\left(i_{t}-i_{t}^{*}\right)$. We generate, $I D 4_{t}=\left(i_{t}-i_{t}^{*}\right)$ and the results of this regression are presented in Table 5a. The computer is giving us the $I D 4 F_{t} \equiv E_{t-1} I D 4_{t}=E_{t-1}\left(i_{t}-i_{t}^{*}\right)$ from the above equation. 
With this forecasting interest differential, $I D 4 F_{t}$, we run eq. (22) and the results shows that $\alpha_{0} \neq \alpha_{2} \neq 0$ (the constant term is statistically significant at $1 \%$ level, then, different than zero; the $\alpha_{2}$ is the same, statistically significant at $1 \%$ level) and $\alpha_{1}=0.979 \cong 1$ (statistically significant at the $1 \%$ level). Thus, the exchange rate market for $(¥ / \$)$ is not very efficient, the "news" affect it and they are not anticipated.

Table 5b. Exchange Rate Expectations and "News", Eq. (22)

\begin{tabular}{|c|c|c|c|c|c|c|c|c|}
\hline & $\alpha_{0}$ & $\alpha_{1}$ & $\alpha_{2}$ & $R^{2}$ & SSR & $F$ & $D-W$ & $N$ \\
\hline$\$ / €$ & $\begin{array}{r}0.004 \\
(0.006)\end{array}$ & $\begin{array}{l}0.976^{* * * *} \\
(0.021)\end{array}$ & $\begin{array}{l}0.010 \\
(0.010)\end{array}$ & 0.940 & 0.073 & $1,069.10$ & 1.641 & 139 \\
\hline$\$ / £$ & $\begin{array}{c}0.012^{* * *} \\
(0.005)\end{array}$ & $\begin{array}{l}0.972^{* * *} \\
(0.010)\end{array}$ & $\begin{array}{c}-0.016^{* * * *} \\
(0.003)\end{array}$ & 0.970 & 0.077 & $5,026.74$ & 1.854 & 312 \\
\hline $\mathrm{C} \$ / \$$ & $\begin{array}{c}0.001 \\
(0.002)\end{array}$ & $\begin{array}{l}0.997^{* * *} \\
(0.007)\end{array}$ & $\begin{array}{c}0.001 \\
(0.006)\end{array}$ & 0.989 & 0.068 & $10,214.14$ & 2.095 & 235 \\
\hline$¥ / \$$ & $\begin{array}{l}0.098^{* * * *} \\
(0.038)\end{array}$ & $\begin{array}{l}0.979^{* * *} \\
(0.008)\end{array}$ & $\begin{array}{l}0.026^{* * *} \\
(0.007)\end{array}$ & 0.983 & 0.090 & $7,283.47$ & 1.791 & 259 \\
\hline
\end{tabular}

Note: See, Table 1.

Source: See, Table 1.

Lastly, the empirical results of eq. (27), determination of the exchange rate risk premium, $\left(r p_{t+1}^{e}\right)$, are presented in Table 6 . We see that the exogenous macro-variables $\left(i_{t}\right.$ and $\left.i_{t}^{*}\right)$, the forecasted variance $\sigma_{t}^{2}(\mathrm{GARCH})$, and the residual $\varepsilon_{t}^{2}(\mathrm{ARCH})$ have no significant effect on the $r p_{t+1}^{e}$ of the $\$ / €$ exchange rate, which proves that the foreign exchange market for $\$ / €$ is efficient. The static forecasting of this $r p_{t+1}^{e}$ appears in Figure 1a and the dynamic forecast in Figure 1b. The market for $\$ / £$ is inefficient because the $r p_{t+1}^{e}$ depends on $\mathrm{ARCH}$ $\left(\varepsilon_{t-1}^{2}=0.189^{* * * *}\right)$ and GARCH $\left(\sigma_{t-1}^{2}=0.672^{* * * *}\right)$. Their static forecast is showed in Figure $2 \mathrm{a}$ and their dynamic in Figure $2 \mathrm{~b}$. The foreign exchange market for $\mathrm{C} \$ / \$$ is also inefficient because the $r p_{t+1}^{e}$ depends on both the exogenous macrovariables $\left(\theta_{i_{t}}=-0.001^{* * * *}\right.$ and $\left.\theta_{i_{t}^{*}}=0.002^{* * * *}\right)$ and on $\operatorname{ARCH}\left(\varepsilon_{t-1}^{2}=-0.044^{* * * *}\right)$ and GARCH $\left(\sigma_{t-1}^{2}=1.049^{* * * *}\right)$. The static forecasting is given in Figure $3 \mathrm{a}$ and the dynamic one in Figure 3b. Lastly, the foreign exchange market for $¥ / \$$ has a volatility $\left(r p_{t+1}^{e}\right)$ that depends on $\theta_{i_{t}}=-0.031^{* * *}$, on $\theta_{i_{t}^{*}}=0.083^{* * *}$, and on ARCH $\left(\varepsilon_{t-1}^{2}=1.078^{* * * *}\right)$, which proves foreign exchange market inefficiency. The Figure 
4a shows the static forecasting and the Figure $4 \mathrm{~b}$ the dynamic forecasting of the $r p_{t+1}^{e}$ of the $¥ / \$$.

Figure 1a. Static Forecasting of the $r p_{t+1}^{e}(\$ / \epsilon)$ : Eqs (25), (24), and (27)

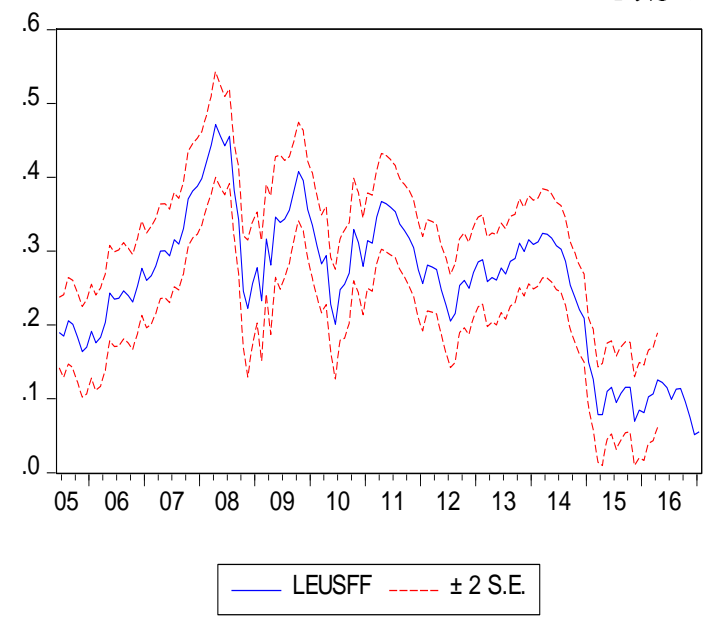

\begin{tabular}{|c|c|}
\hline \\
\hline \multicolumn{2}{|l|}{$\begin{array}{l}\text { Forecast: LEUSFF } \\
\text { Actual: LEUSF }\end{array}$} \\
\hline \multicolumn{2}{|c|}{ Forecast sample: 1971M01 2017M12 } \\
\hline \multicolumn{2}{|c|}{ Adjusted sample: 2005M06 2017M01 } \\
\hline \multicolumn{2}{|c|}{ Included observations: 130} \\
\hline Root Mean Squared Error & 0.022580 \\
\hline Mean Absolute Error & 0.016868 \\
\hline Mean Abs. Percent Error & 6.959428 \\
\hline Theil Inequality Coefficient & 0.039913 \\
\hline Bias Proportion & 0.000000 \\
\hline Variance Proportion & 0.021753 \\
\hline Covariance Proportion & 0.978247 \\
\hline
\end{tabular}

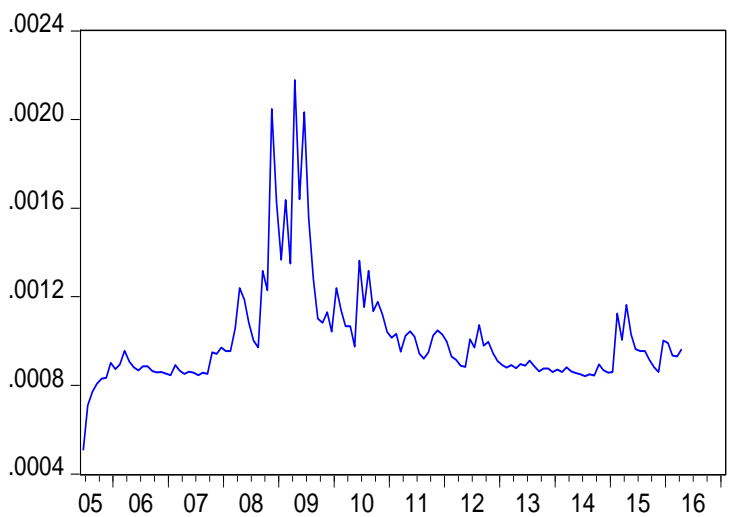

Forecast of Variance

Note: See, Table 6. LEUSFF=LEUSF-LEUF $=r p_{t+1}^{e}=s_{t+1}^{e}-f_{t}(\$ / €)$.

Source: See, Table 1. 
Figure 1b. Dynamic Forecast of the $r p_{t+1}^{e}(\$ / \epsilon)$ : Eq. (25), (24), and (27) (LEUSFLEUF)

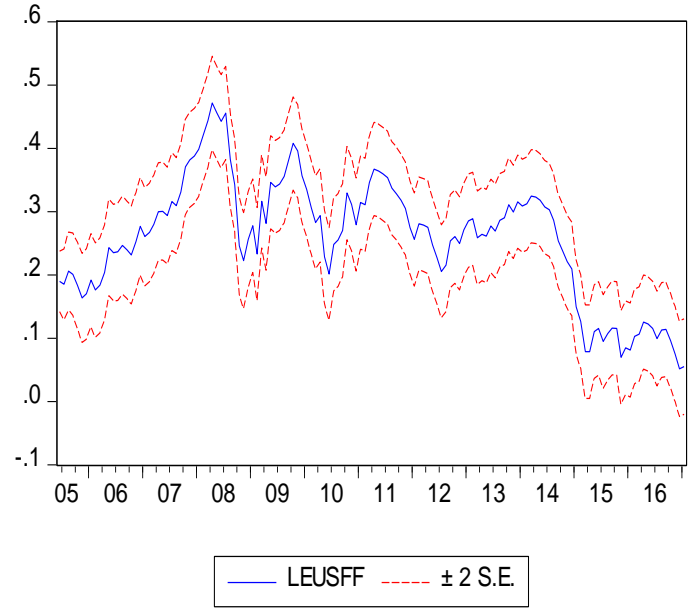

Forecast: LEUSFF

Actual: LEUSF

Forecast sample: 1971M01 2017M12 Adjusted sample: 2005M06 2017M01 Included observations: 130 Root Mean Squared Error $\quad 0.022580$ Mean Absolute Error Mean Abs. Percent Error 0.016868 Theil Inequality Coefficient 6.959428 Bias Proportion 0.039913 Variance Proportion 0.000000 Covariance Proportion

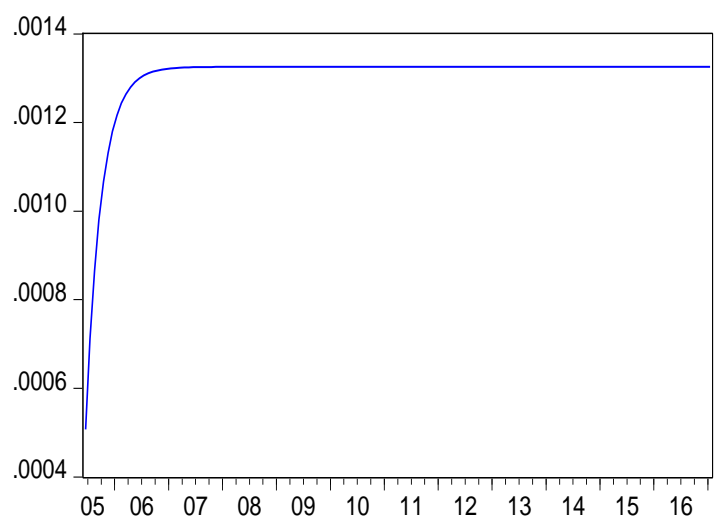

Forecast of Variance

Note: See, Table 6. LEUSFF=LEUSF-LEUF $=r p_{t+1}^{e}=s_{t+1}^{e}-f_{t}(\$ / €)$.

Source: See, Table 1. 
Figure 2a. Static Forecasting of the $r p_{t+1}^{e}$ (\$/£): Eqs (25), (24), and (27)

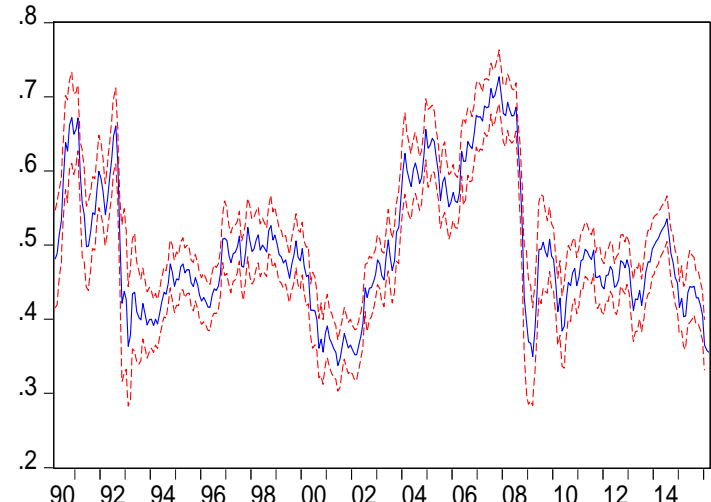

Forecast: LUKSFF

Actual: LUKSF

Forecast sample: 1971M01 2017M12

Adjusted sample: 1990M03 2016M03

Included observations: 310

Root Mean Squared Error $\quad 0.022212$

Mean Absolute Error

0.016602

Mean Abs. Percent Error 3.383462

Theil Inequality Coefficient $\quad 0.022030$

Bias Proportion $\quad 0.000245$

Variance Proportion $\quad 0.011758$

Covariance Proportion $\quad 0.987997$

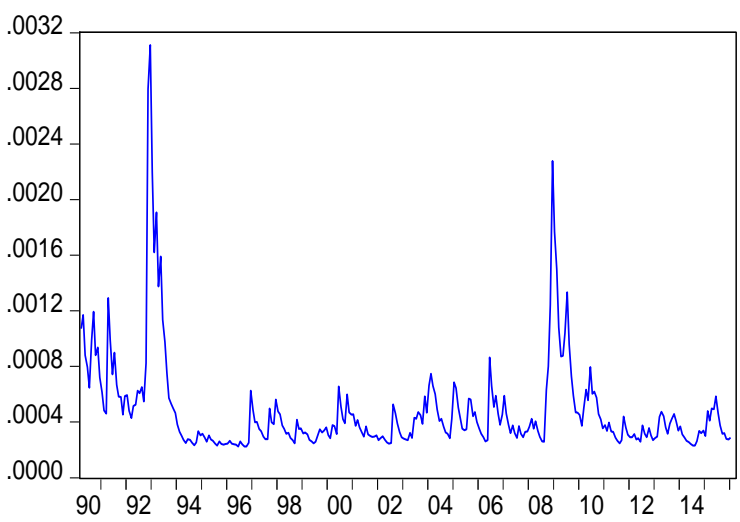

Forecast of Variance

Note: See, Table 6. LUKSFF=LUKSF-LUKF $=r p_{t+1}^{e}=s_{t+1}^{e}-f_{t}(\$ / \mathfrak{f})$.

Source: See, Table 1. 
Figure 2b. Dynamic Forecast of the $r p_{t+1}^{e}$ (\$/£): Eq. (25), (24), and (27) (LUKSFLUKF)

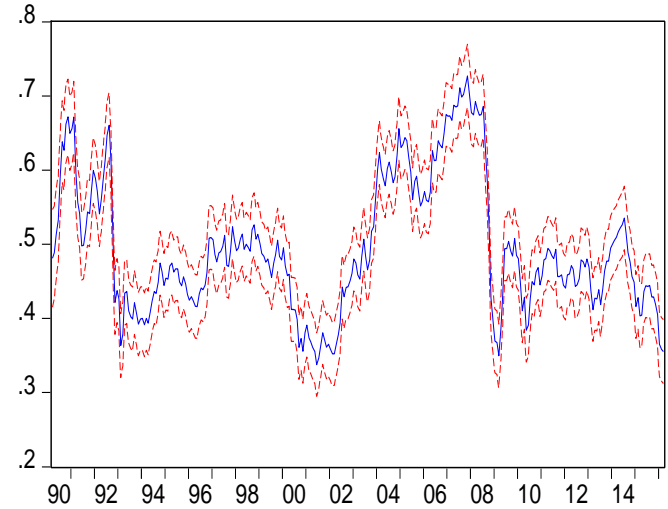

Forecast: LUKSFF

Actual: LUKSF

Forecast sample: 1971M01 2017M12 Adjusted sample: 1990M03 2016M03 Included observations: 310

Root Mean Squared Error $\quad 0.022212$

Mean Absolute Error 0.016602

Mean Abs. Percent Error

3.383462

Theil Inequality Coefficient $\quad 0.022030$

Bias Proportion

0.000245

Variance Proportion

0.011758

Covariance Proportion

0.987997

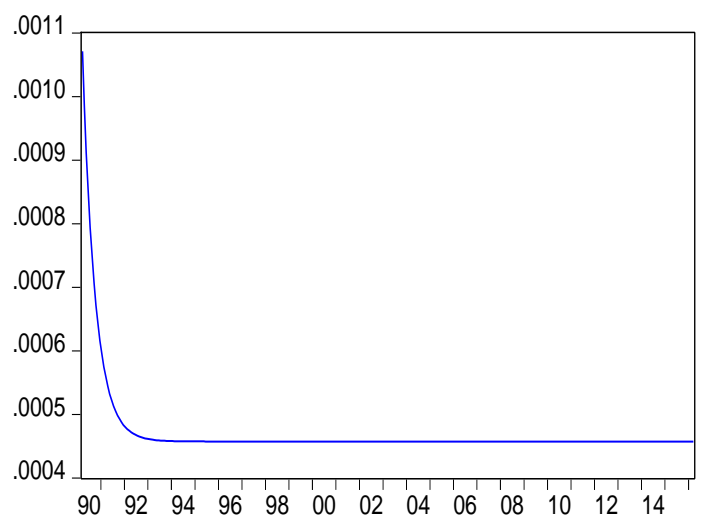

Forecast of Variance

Note: See, Table 6. LUKSFF=LUKSF-LUKF $=r p_{t+1}^{e}=s_{t+1}^{e}-f_{t}(\$ / \mathfrak{f})$.

Source: See, Table 1. 
Figure 3a. Static Forecasting of the $r p_{t+1}^{e}(C \$ / \$)$ : Eqs (25), (24), and (27)

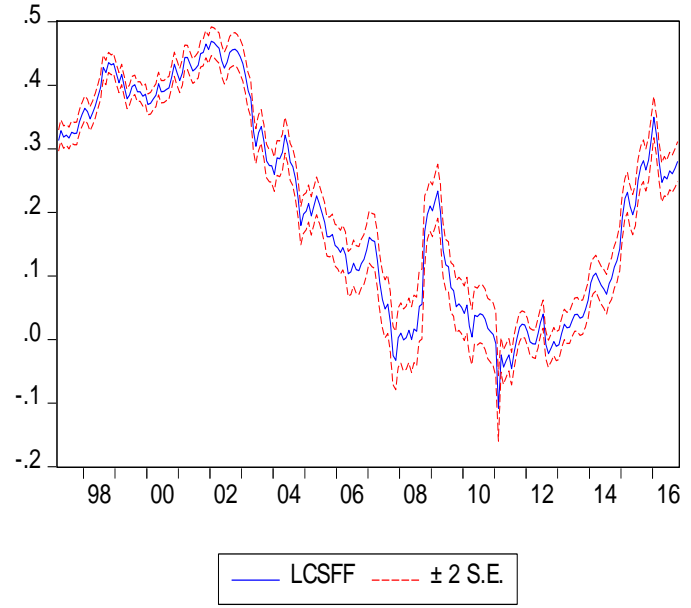

Forecast: LCSFF

Actual: LCSF

Forecast sample: 1971M01 2017M12

Adjusted sample: 1997M03 2016M10

Included observations: 236

Root Mean Squared Error $\quad 0.016672$

Mean Absolute Error

0.011682

Mean Abs. Percent Error $\quad 94.27685$

Theil Inequality Coefficient 0.031546

Bias Proportion $\quad 0.001898$

Variance Proportion $\quad 0.003276$

Covariance Proportion $\quad 0.994826$

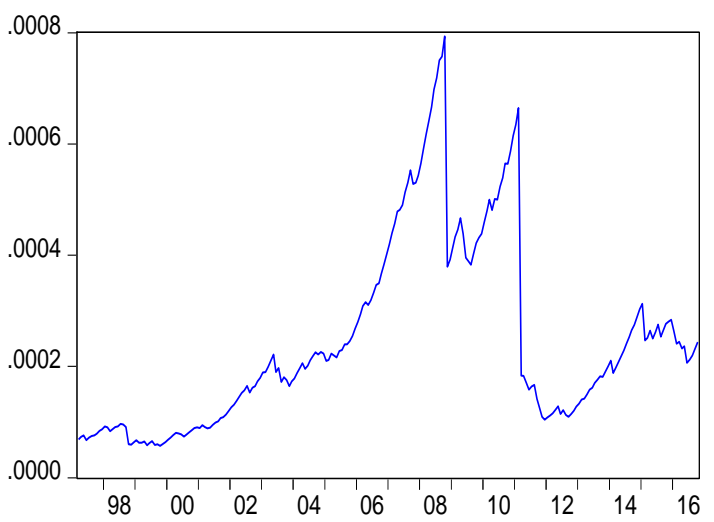

Forecast of Variance

Note: See, Table 6. LCSFF=LCSF-LCF $=r p_{t+1}^{e}=s_{t+1}^{e}-f_{t}(\mathrm{C} \$ / \$)$.

Source: See, Table 1. 
Figure 3b. Dynamic Forecast of the $r p_{t+1}^{e}(C \$ / \$)$ : Eq. (25), (24), and (27) (LCSF$L C F$ )

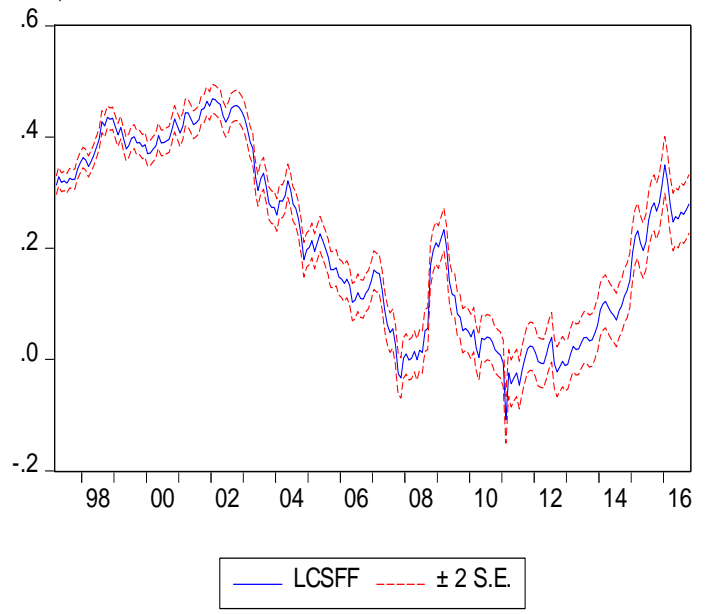

Forecast: LCSFF

Actual: LCSF

Forecast sample: 1971M01 2017M12

Adjusted sample: 1997M03 2016M10

Included observations: 236

Root Mean Squared Error $\quad 0.016672$

Mean Absolute Error $\quad 0.011682$

Mean Abs. Percent Error $\quad 94.27685$

Theil Inequality Coefficient $\quad 0.031546$

Bias Proportion $\quad 0.001898$

Variance Proportion $\quad 0.003276$

Covariance Proportion $\quad 0.994826$

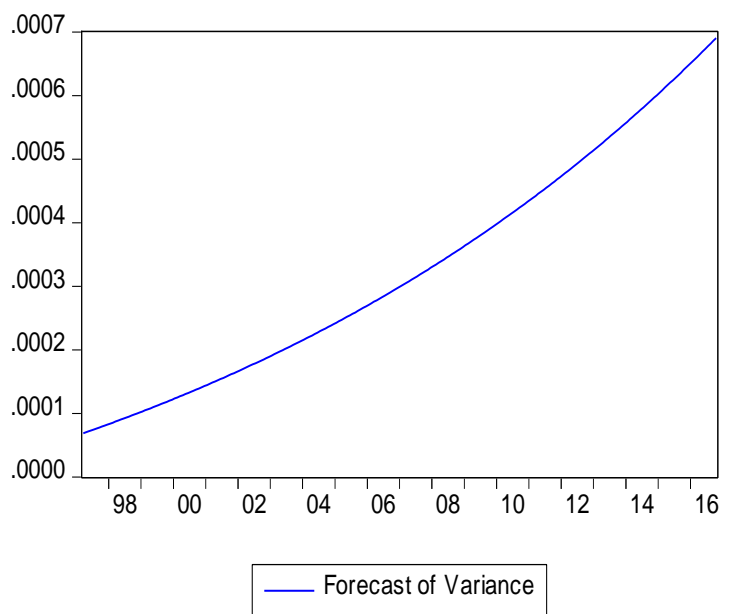

Note: See, Table 6. LCSFF=LCSF-LCF $=r p_{t+1}^{e}=s_{t+1}^{e}-f_{t}(\mathrm{C} \$ \mathbf{\$})$.

Source: See, Table 1. 
Figure 4a. Static Forecasting of the $r p_{t+1}^{e}(¥ / \$)$ : Eqs (25), (24), and (27)

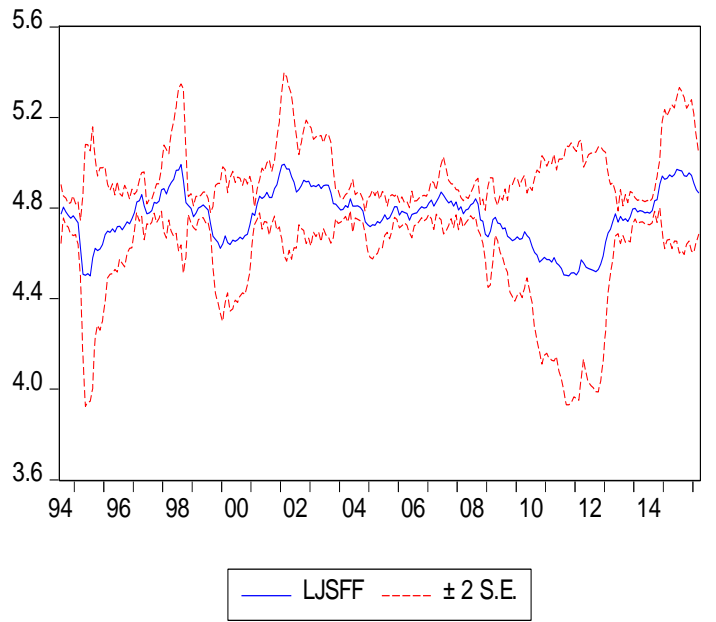

Forecast: LJSFF

Actual: LJSF

Forecast sample: 1971M01 2017M12

Adjusted sample: 1994M07 2016M03

Included observations: 261

Root Mean Squared Error $\quad 0.123342$

Mean Absolute Error $\quad 0.094845$

Mean Abs. Percent Error 1.980095

Theil Inequality Coefficient $\quad 0.012911$

Bias Proportion

0.053218

Variance Proportion

$\mathrm{NA}$

Covariance Proportion NA

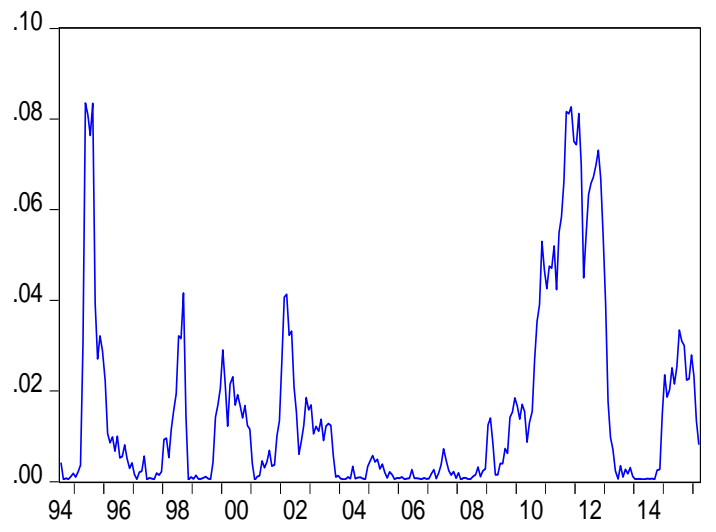

Forecast of Variance

Note: See, Table 6. LJSFF=LJSF-LJF $=r p_{t+1}^{e}=s_{t+1}^{e}-f_{t}(¥ / \$)$.

Source: See, Table 1. 
Figure 4b. Dynamic Forecast of the $r p_{t+1}^{e}(¥ / \$)$ : Eq. (25), (24), and (27) (LJSF-

$L J F)$
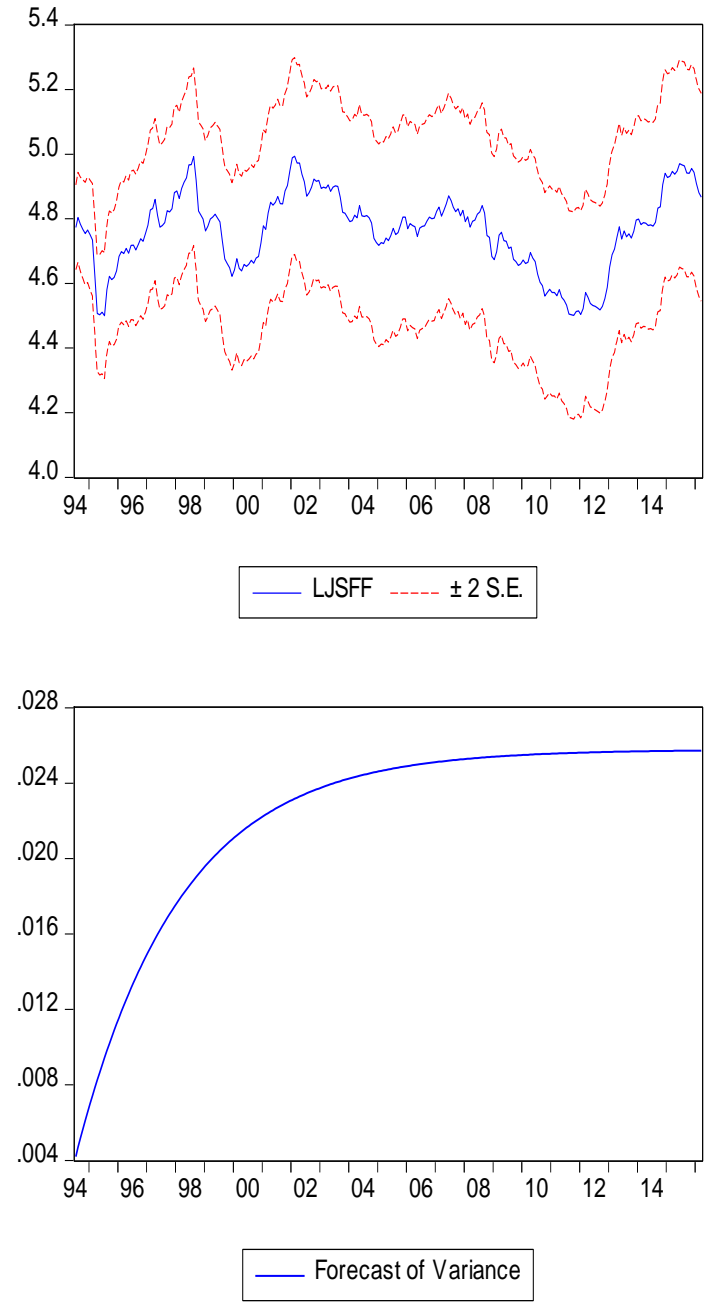

Note: See, Table 6. LJSFF=LJSF-LJF $=r p_{t+1}^{e}=s_{t+1}^{e}-f_{t}(¥ / \$)$.

Source: See, Table 1.
Forecast: LJSFF

Actual: LJSF

Forecast sample: 1971M01 2017M12

Adjusted sample: 1994M07 2016M03

Included observations: 261

Root Mean Squared Error $\quad 0.123342$

Mean Absolute Error $\quad 0.094845$

Mean Abs. Percent Error 1.980095

Theil Inequality Coefficient $\quad 0.012911$

Bias Proportion $\quad 0.053218$

Variance Proportion NA

Covariance Proportion NA 
Table 6. Estimation of Eq. (27) with the use of Eqs. (24) and (25)

Risk Premium Determination $\left(s_{t+1}^{e}-f_{t}=r p_{t+1}^{e}\right)$

\begin{tabular}{|c|c|c|c|c|}
\hline Variables & $L E U S F-L E U F$ & $L U K S F-L U K F$ & $L C S F-L C F$ & $L J S F-L J F$ \\
\hline$C$ & $\begin{array}{l}-0.001 \\
(0.006)\end{array}$ & $\begin{array}{c}0.001 \\
(0.002)\end{array}$ & $\begin{array}{l}-0.002^{* *} \\
(0.001)\end{array}$ & $\begin{array}{l}0.153^{* * *} \\
(0.006)\end{array}$ \\
\hline$S T T 3 M_{t}$ & $\begin{array}{l}-0.002 \\
(0.007)\end{array}$ & $\begin{array}{l}0.001 \\
(0.001)\end{array}$ & $\begin{array}{l}-0.001^{* * * *} \\
(0.001)\end{array}$ & $\begin{array}{c}-0.031^{* * *} \\
(0.002)\end{array}$ \\
\hline$S T T 3 M_{t}^{*}$ & $\begin{array}{c}0.001 \\
(0.006)\end{array}$ & $\begin{array}{l}-0.001 \\
(0.001)\end{array}$ & $\begin{array}{l}0.002^{* * * *} \\
(0.001)\end{array}$ & $\begin{array}{l}0.083^{* * * *} \\
(0.006)\end{array}$ \\
\hline
\end{tabular}

Variance Equation

$\begin{array}{lccll}C & 0.001 & 0.001^{* *} & 0.001 & 0.001^{* * * *} \\ \varepsilon_{t-1}^{2} & (0.001) & (0.001) & (0.001) & (0.001) \\ & 0.150 & 0.189^{* * *} & -0.044^{* * *} & 1.078^{* * * *} \\ \sigma_{t-1}^{2} & (0.287) & (0.050) & (0.006) & (0.275) \\ & 0.600 & 0.672^{* * *} & 1.049^{* * *} & -0.101 \\ & (0.640) & (0.100) & (0.012) & (0.162)\end{array}$

$\begin{array}{lcccc}R^{2} & 0.001 & 0.009 & -0.005 & 0.238 \\ S S R & 0.066 & 0.153 & 0.066 & 3.971 \\ D-W & 1.708 & 1.389 & 1.991 & 0.046 \\ N & 130 & 310 & 236 & 261 \\ R M S E & 0.022580 & 0.022212 & 0.016672 & 0.123342\end{array}$

Note: $L E U S=\ln$ of $\$ / €$ spot rate, $L U K S=\ln$ of $\$ / \mathfrak{f}$ spot rate, $L C S=\ln$ of $C \$ / \$$ spot rate, $L J S=$ ln of $\$ \not$ spot rate, $L S_{t}=\ln$ of spot exchange rate, $S T T 3 M_{t}=$ short term Treasury-Bill 3month, $S T T 3 M_{t}^{*}=$ short term foreign Treasury-Bill 3-month, $* * *$ significant at the $1 \%$ level, ** significant at the $5 \%$ level, and $*$ significant at the $10 \%$ level. LEUSF - LEUF $=$ risk premium $\left(s_{t+1}^{e}-f_{t}=r p_{t+1}^{e}\right)$.

Source: See, Table 1.

\section{Policy Implications}

The exchange rates have been very volatile since the 1970s, when the exchange rates became flexible (Kallianiotis 2016b). As an example, the standard deviation of the spot exchange rate between the U.S. dollar and the euro has been, $\sigma_{s}= \pm 0.18 \%$ per month; between U.S. dollar and British pound, $\sigma_{s}= \pm 0.31 \%$; between Canadian dollar and U.S. dollar, $\sigma_{s}= \pm 0.17 \%$ and between Japanese yen and U.S. dollar, $\sigma_{s}= \pm 73.99 \%$. Thus, the predictability of the exchange rate has become very difficult. These two characteristics of exchange rates (volatility 
and unpredictability) are typical of auction asset markets and have worsened after 2008 with the global financial crisis and the new systemic risk that the world economies are facing, due to their high positive correlation $\left(\rho_{Y, Y^{*}} \cong+1\right)$.

In our foreign currency markets, current spot exchange rates reflect expectations concerning the future course of events (market, political, economic, international) and new information (global news are instantaneously known to everyone), which induces changes in expectations and are immediately reflected in corresponding changes in exchange rates (and all asset prices); thus, reducing unexploited profit opportunities from arbitrage. However, speculators, insiders, and market makers are thriving and proving, at the same time that the inefficiency in all the assets markets is well holding, with the covered exhortation of the Fed (monetary policy). (Kallianiotis 2017c).

The strong dependence of current prices (spot exchange rates) on expectations about the future is unique to the determination of asset prices. This strong dependence causes many problems in our economy and our social welfare; especially in periods that are dominated by uncertainties, new information, rumors (propagandas), announcements and "news" (the directed media plays a major role in today's social welfare). ${ }^{11}$ All these, mostly negative "news" change our expectations (make us, mostly, pessimistic) and are the prime cause of fluctuations in asset prices (together with a strange monetary policy). ${ }^{12}$ Consequently, since the information, which alters expectations are new ("news"), the resulting fluctuations in price (exchange rate) cannot be predicted by lagged forward exchange rates, which are based on past information. During these uncertain periods, we should expect exchange rates (and all other asset prices) to exhibit large fluctuations. Thus, past prices, which are based on past information, might be imprecise to forecast future prices. The new information cannot be anticipated and these "surprises" are affecting the spot exchange rates. Figure 1 shows the exchange rate movements of our four exchange rates and Table 7 gives the correlation between these rates.

\footnotetext{
${ }^{11} \mathrm{We}$ need to do some diversification of the different sources of news (domestic and foreign) and to derive our own conclusion and inferences. We live in the century of political correctness ("the big lie"), liberalism, imposed integration, encouraged civil unrests, and globalization. The controlled and subjective mass media have contributed to these problems. The world "planners" started with Europe and Europeans, the most advanced continent and by integrated (control) them, it will be easy for the rest of the world to be persuaded to accept without serious resistance the globalization. See, http://www.goodreads.com/author/quotes/9951.David_Rocke feller).

${ }^{12}$ Zero federal funds rate for seven years by the U.S. Fed and capital controls by the ECB. Policies, which are not very effective.
} 
Figure 1. Exchange Rate Movement (European Terms, FC/\$)

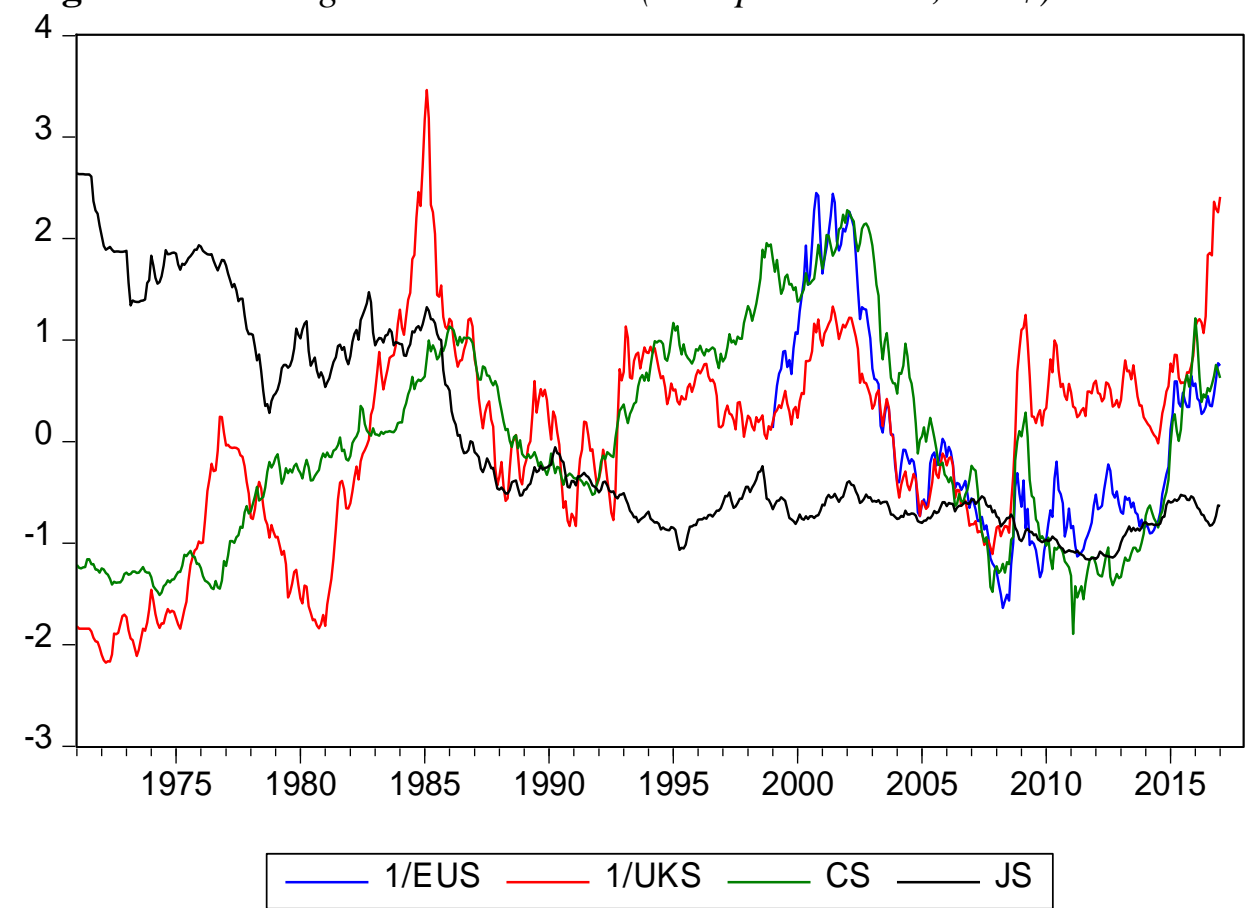

Note: $1 /$ EUS $(€ / \$), 1 /$ UKS $(£ / \$)$, CS (C\$ $\$$ ), and JS $(¥)$.

Source: See, Table 1.

Table 7. Correlation between the Exchange Rates

\begin{tabular}{|c|c|c|c|c|}
\hline & 1/EUS & 1/UKS & CS & JS \\
\hline 1/EUS & 1.000 & & & \\
\hline 1/UKS & 0.571 & 1.000 & & \\
\hline CS & 0.897 & 0.405 & 1.000 & \\
\hline JS & 0.570 & -0.032 & 0.681 & 1.000 \\
\hline
\end{tabular}

Note: 1/EUS (€/\$), 1/UKS (£/\$), CS (C\$/\$), and JS (¥).

Source: See, Table 1.

In addition, the historical data (Kallianiotis (2016b) show that: (1) $\bar{S}_{1}=1.211$ $\$ / €, \quad \sigma_{S_{1}}^{2}=0.031081$; the expected $s_{t+1}^{e}-f_{t}=r p_{t+1}^{e}=-0.001180$ and $\sigma_{t p_{t+1}^{e}}^{2}=0.000924$; the actual $S_{t}-F_{t-3}=R P_{t}=-0.006278, \quad \sigma_{R P_{1}}^{2}=0.00418337$; and $\ln$ of the actual $s_{t}-f_{t-3}=r p_{t}=-0.00513, \quad \sigma_{r p_{1}}^{2}=0.00234585 \quad$. (2) $\bar{S}_{2}=1.751 \$ / £, \sigma_{S_{2}}^{2}=0.0965208$; $r p_{t+1}^{e}=-0.00101, \quad \sigma_{r p_{t+1}^{e}}^{2}=0.0009593887 ; \quad R P_{t}=-0.004141, \quad \sigma_{R P_{1}}^{2}=0.005528517 ;$ and $r p_{t}=-0.002469, \quad \sigma_{r p_{1}}^{2}=0.001934856$. (3) $\bar{S}_{3}=1.216 \quad \mathrm{C} \$ / \$, \quad \sigma_{S_{3}}^{2}=0.028301669$; the expected $s_{t+1}^{e}-f_{t}=r p_{t+1}^{e}=0.00000305$ and $\sigma_{r p_{t+1}^{e}}^{2}=0.000650352 ;$ the actual $S_{t}-F_{t-3}=R P_{t}=-0.000272, \quad \sigma_{R P_{3}}^{2}=0.0022174681 ;$ and $\ln$ of the actual 
$s_{t}-f_{t-3}=r p_{t}=-0.000273, \quad \sigma_{r p_{1}}^{2}=0.001525527 \quad$ (4) $\bar{S}_{4}=162.590 ¥ / \$, \sigma_{S_{4}}^{2}=5,474.5852$; $r p_{t+1}^{e}=0.093852, \quad \sigma_{r p_{t+1}^{e}}^{2}=0.023381162 ; \quad R P_{t}=-0.289028, \quad \sigma_{R P_{4}}^{2}=33.357405, \quad$ and $r p_{t}=-0.002593, \sigma_{r p_{1}}^{2}=0.002600898$. These existing risk premia show that the foreign exchange market is not very efficient.

We are in an informational disequilibrium or an informational discord that has created enormous social cost and distress in modern times. Actually, this leads to a distribution of wealth from one normal investor to the other investor (speculator) and a transference of risk from the speculator to the hard working saver. The public forms its expectations by using $I_{t}$ instead of $\Pi_{t}$ and damages the economy and diminishes the social welfare of the country. The role of academics is to teach the public; the role of public policy is to set and achieve social objectives through regulations and a fair tax system. The ideal situation for the Fed would be to have complete knowledge of the economy's structure and of all the random events that might impact it. If the Fed had an attainable objective, it could set its policies accordingly and achieve that goal. Some people believe that Federal Reserve officials have a sort of second sight that they use to foretell the future. But the truth is that the best economic forecasting is second rate when compared to the public's expectation. No one understands the economy's structure with enough precision to keep it perpetually humming along in balance and at top speed. Unfortunately, policymakers necessarily rely on second-best solutions. ${ }^{13}$ During the latest global financial crisis, the monetary policy (Quantitative Easing) with zero interest rate from December 2008 to December 2015 was completely ineffective and efficiency has disappeared from the markets because people stopped to trust the financial market anymore. This global financial crisis is still going on in Europe for ten years and has made Europeans' lives very difficult.

Furthermore, exchange rates respond to surprises, to news, and to human actions due to ignorance of $\Pi_{t}$ and knowledge of $I_{t}$ only. But these surprises are unpredictable. Because exchange rates respond sensitively to the unexpected events that randomly hit markets, exchange rates themselves also move randomly. This is the nature of market efficiency and has unfortunately become our second nature, too. Investors have no other choice except to accept the market efficiency because the spot markets are following the futures markets without any questions and if someone ignores the futures market, he will have enormous losses and will go bankrupt. We are enslaved to the futures markets, and for this reason, we have to regulate these markets. ${ }^{14}$

\footnotetext{
${ }^{13}$ See, Economic Trends, Federal Reserve Bank of Cleveland, August 1994, p. 1.

${ }^{14}$ For trading foreign currency, see, https://www.nfa.futures.org/NFA-investor-information/pu blication-library/forex.HTML
} 


\section{Conclusions}

The empirical results show that foreign exchange market is relatively efficient. Based on the above theories, it was expected a high correlation between movements of spot and forward rates. The correlation coefficient and the causality tests show that the forward rates cause the spot rates. (For the test of stationary, see, Kallianiotis 2017a). They are for the $(\$ / €),\left(\rho_{s, f}=+0.983\right)$ and $\left(f \Rightarrow 20.955^{* * * * *} s\right)$, for $(\$ / £)$ is $\left(\rho_{s, f}=+0.991\right)$ and $\left(f \Rightarrow 117.218^{* * * * *} s\right)$, for the $(\mathrm{C} \$ / \$)$ is $\left(\rho_{s, f}=+0.983\right)$ and $\left(f \Rightarrow 57.405^{* * * *} s\right)$, and for $(¥ / \$)$ is $\left(\rho_{s, f}=+0.995\right)$ and ( $f \Rightarrow 116.313^{* * * *} s$ ), because both rates respond at the same time to the same flow of new information (permanent or transitory). Also, the contemporaneous spot and forward exchange rates are approximately equal, showing that the market's best forecast of the future spot rate is the current spot rate. This phenomenon reveals that exchange rates follow a random walk process.

In these specification models, we tested the hypothesis that the foreign exchange market is efficient and we argued that the forward rate fully reflects the limited available information (due to the lack of complete and correct global knowledge) about the exchange rate expectations and the forward rate. Thus, the forward rate is usually viewed by the market participants as an unbiased predictor of the future spot rate. The conventional test of the unbiasedness hypothesis that we used was a regression estimation by fitting the current spot on the one-period lagged spot rate, on the one-period lagged forward rate, on the one-period lagged spot and forward rate, the exchange rate predictability, and on the one-period lagged forward rate and the "news". These tests involve the joint hypothesis that the constant terms do not differ from zero, that the coefficients on the one-period lagged spot and forward rates do not significantly differ from one, that the sum of the coefficients of the one period lagged spot and forward rates do not significantly differ from one, that the coefficient of the "news" is not different from zero, and that the error terms pass some statistical tests (serial correlation, normality, homoscedasticity, ARCH, etc.).

Lastly, the empirical results show that we cannot reject the unbiased hypothesis for U.S.A. and Euro-zone, but for the U.K. and Japan it is rejected. The results imply that we can use the forward rate as a proxy for the prediction of the spot rate next period between dollar and euro $(\$ / €)$. There is some instability in the parameters of almost all the equations of the model, but, from a forecasting point of view, this is consistent with the least cost approach to the economic agents, although it may not yield the minimum forecast error due to interventions, incomplete and partial knowledge (incorrect information), and simplicity in modeling. The overall results show that the foreign exchange markets for both the U.S. and Euro-zone are pretty efficient and the forward rate predicts the future spot rate $\left(r p_{t} \cong 0\right)$. The Canadian dollar and the U.S. dollar exchange rate is also very efficient, but there is a small $r p_{t}$. Britain's and Japan's market efficiencies are questionable. The unanticipated events ("news") are affecting $£$ and $¥$ and there exists a $r p_{t}$ between the forward and the spot rate. 
Further diagnostic tests, like heteroskedasticity, residual, specification, and stability tests are useful to be applied for the above models.

\section{References}

Bilson J (1978) Rational Expectations and the Exchange Rate. In J Frenkel, HG Johnson (eds) The Economics of Exchange Rates. Reading MA: Addison-Wesley.

Chomsky N (2014) The Death of the American University. Vox Populi, (2014), February, 1-4. Retrieved from https://voxpopulisphere.com/2014/08/10/noam-chomsky-thedeath-of-the-american-university/.

Davidson JD (2015) The Age of Deception: Decoding the Truths About the U.S. Economy. New York: Strategic Investment.

Dornbusch R (1978) Monetary Policy under Exchange Rate Flexibility. In Managed Exchange-Rate Flexibility: The Recent Experience. Federal Reserve Bank of Boston Conference Series, No. 20.

Enders Walter (1995) Applied Econometric Time Series. New York, N.Y.: John Wiley $\&$ Sons, Inc.

Engle RF, Lilien DM, Robins RP (1987) Estimating Time Varying Risk Premia in the Term Structure: The ARCH-M Model. Econometrica 55: 391-407.

Fama E (1970) Efficient Capital Markets: A Review of Theory and Empirical Work. Journal of Finance 25(May): 383-417.

Frenkel JA (1984) Flexible Exchange Rates, Prices, and the Role of 'News': Lessons from the 1970s. In JS Bhandari, BH Putnam (eds.) Economic Interdependence and Flexible Exchange Rates 3-41. Cambridge, MA: The MIT Press.

Frenkel JA, Mussa ML (1980) The Efficiency of Foreign Exchange Markets and Measures of Turbulence. American Economic Review 70: 374-381.

Giovannini A, Jorion P (1987) Interest Rates and Risk Premia in the Stock Market and in the Foreign Exchange Market. Journal of International Money and Finance 6(1): 107-124.

Isard P (1980) Expected and Unexpected Changes in Exchange Rates: The Role of Relative Price Levels, Balance-of-Payments Factors, Interest Rates and Risk. Federal Reserve Board, International Finance Discussion Papers, No. 156.

Kallianiotis IN (2017a) Exchange Rate Movement: Efficiency in the Foreign Exchange Market. International Research Journal of Applied Finance VIII(4): 195-213.

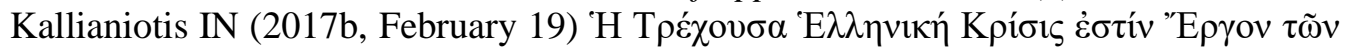

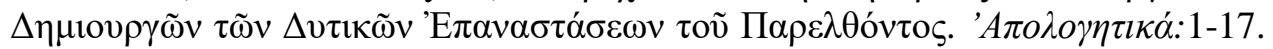
Retrieved from http://apologitikaa.blogspot.com.cy/2017/02/i.html

Kallianiotis IN (2017c) Central Banks, Monetary Policy, and their Efficiency, chapter 1. In H Ward (ed.) Monetary Policy: Perspectives, Strategies and Challenges. New York: Nova Science Publishers.

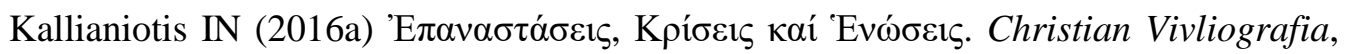
December 2, 1-6. Retrieved from http://bit.ly/2Ep82P3.

Kallianiotis IN (2016b) Factors Affecting the Exchange Rate Risk premium. Journal of Applied Finance and Banking 6(6): 33-55.

Kallianiotis JN (2013a) Exchange Rates and International Financial Economics: History, Theories, and Practices. New York: Palgrave MacMillan.

Kallianiotis JN (2013b) International Financial Transactions and Exchange Rates: Trade, Investment, and Parities. New York: Palgrave MacMillan. 
Kallianiotis IN (2012, February) The Generative Motive of European Union and its Latest Struggle for Survival. International Journal of Business and Commerce 1(6):1-24.

Mishkin FS (1983) A Rational Expectations Approach to Macroeconomics. Chicago: University of Chicago Press.

Muth JF (1961) Rational Expectations and the Theory of Price Movements. Econometrica 29: 315-335.

Smith P, Soresen S, Wickens M (2003) Macroeconomic Sources of Equity Risk, CEPR Discussion Paper No. 4070. 